Conduct of Operations Applicability Matrix for CMELS Light Science and Industry and General Industry Facilities at LLNL Site 200

G. A. Cooper

April 25, 2008 
This document was prepared as an account of work sponsored by an agency of the United States government. Neither the United States government nor Lawrence Livermore National Security, LLC, nor any of their employees makes any warranty, expressed or implied, or assumes any legal liability or responsibility for the accuracy, completeness, or usefulness of any information, apparatus, product, or process disclosed, or represents that its use would not infringe privately owned rights. Reference herein to any specific commercial product, process, or service by trade name, trademark, manufacturer, or otherwise does not necessarily constitute or imply its endorsement, recommendation, or favoring by the United States government or Lawrence Livermore National Security, LLC. The views and opinions of authors expressed herein do not necessarily state or reflect those of the United States government or Lawrence Livermore National Security, LLC, and shall not be used for advertising or product endorsement purposes.

This work performed under the auspices of the U.S. Department of Energy by Lawrence Livermore National Laboratory under Contract DE-AC52-07NA27344. 


\title{
Appendix C Conduct of Operations Applicability Matrix \\ Conduct of Operations Applicability Matrix for CMELS Light Science and Industry Facilities at LLNL Site 200
}

\section{April 2008}

\author{
LLNL-TR-403182
}

This Worksheet applies to the following facilities:
Building $133 \quad$ Building 241
Building $243 \quad$ Building 281
Building $292 \quad$ Building 293
Building $294 \quad$ Building 361
Building $362 \quad$ Building 366
Building $373 \quad$ Building 378

Building 379

DISCLAIMER

\begin{abstract}
This document was prepared as an account of work sponsored by an agency of the United States government. Neither the United States government nor Lawrence Livermore National Security, LLC, nor any of their employees makes any warranty, expressed or implied, or assumes any legal liability or responsibility for the accuracy, completeness, or usefulness of any information, apparatus, product, or process disclosed, or represents that its use would not infringe privately owned rights. Reference herein to any specific commercial product, process, or service by trade name, trademark, manufacturer, or otherwise does not necessarily constitute or imply its endorsement, recommendation, or favoring by the United States government or Lawrence Livermore National Security, LLC. The views and opinions of authors expressed herein do not necessarily state or reflect those of the United States government or Lawrence Livermore National Security, LLC, and shall not be used for advertising or product endorsement purposes.
\end{abstract}




\section{Conduct of Operations Applicability Matrix}

This Matrix applies to the following facilities:

Building 133, Building 241, Building 243, Building 281, Building 292, Building 293,

Building 294, Building 361, Building 362, Building 366, Building 373, Building 378 ,

Building 379

Matrix table based on the LLNL Environment Safety \& Health Manual Document 3.5, Conduct of Operations for LLNL Facilities

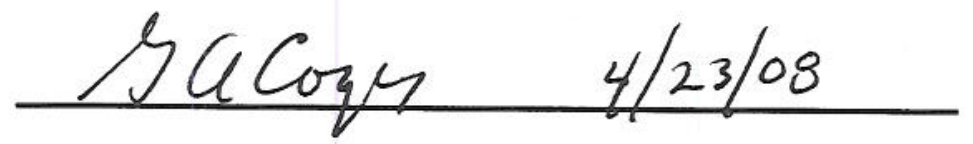

Prepared by Greg Cooper, AD Facility Manager, CMELS

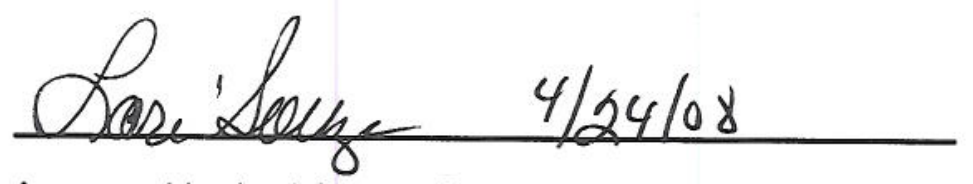

Approved by Lori Souza, Deputy AD, Operations, CMELS

NNSA/LSO Approval

This document has been reviewed and verified not to contain classified information. ADC'ed by Laura Gilliom on April 23, 2008. 


\section{Conduct of Operations Applicability Matrix for Light Science \& Industry Facilities}

The following table documents applicability of the Conduct of Operations elements per ES\&H Manual Document 3.5, Conduct of Operations for LLNL Facilities, to operations in LLNL facilities. Applicable implementing documents, processes, and programs are listed.

\begin{tabular}{|c|c|c|c|c|}
\hline $\begin{array}{l}\text { ES\&H MANUAL } \\
\text { DOCUMENT } 3.5 \\
\text { SECTION }\end{array}$ & $\begin{array}{l}\text { REQUISITES FOR SECTION } \\
\text { ELEMENTS }\end{array}$ & $\begin{array}{l}\text { APPLICABLE } \\
\text { YES/NO }\end{array}$ & $\begin{array}{l}\text { RESPONSIBILITY } \\
\text { FOR } \\
\text { COMPLIANCE } \\
\text { FMC/PMC }^{1}\end{array}$ & $\begin{array}{l}\text { COMMENTS AND/OR REFERENCE FOR } \\
\text { VERIFICATION OF COMPLIANCE }\end{array}$ \\
\hline \multicolumn{5}{|l|}{$\begin{array}{l}\text { OPERATIONS } \\
\text { ORGANIZATION } \\
\text { ADMINISTRATION } \\
\text { SECTION } 1.0\end{array}$} \\
\hline $\begin{array}{l}\text { 1.2.1. Operations } \\
\text { Policies }\end{array}$ & $\begin{array}{l}\text { Operating policies and procedures } \\
\text { should be defined (e.g., FSPs, IWS, } \\
\text { IWS/SPs, Work Procedures, Standard } \\
\text { Operating Procedures [SOPs]) } \\
\text { including responsibilities for } \\
\text { implementation. }\end{array}$ & Yes & FMC/PMC & $\begin{array}{l}\text { LLNL ES\&H Manual Documents } 2.1 \text { \& } 2.2 \\
\text { CMELS-330, ISMS Implementation Plan } \\
\text { CMLS-411, FSP } 360 \text { Complex } \\
\text { CMLS-412, FSP } 360 \text { Complex, Biohazardous } \\
\text { Operations }\end{array}$ \\
\hline \multirow[t]{2}{*}{ 1.2.2. Resources } & $\begin{array}{l}\text { A long-range staffing plan that } \\
\text { anticipates personnel losses should } \\
\text { be developed and implemented for } \\
\text { key positions that require special } \\
\text { training/ qualification, certificates } \\
\text { and/or licenses. }\end{array}$ & No & NA & $\begin{array}{l}\text { There are no Key Positions identified for which } \\
\text { special training/qualification, certificate and/or } \\
\text { licenses are required. }\end{array}$ \\
\hline & $\begin{array}{l}\text { Staffing levels should comply with the } \\
\text { level of ES\&H support specified in } \\
\text { resource planning documents. }\end{array}$ & Yes & FMC/PMC & $\begin{array}{l}\text { CMELS-330 and ES\&H Manual Document } 2.1 \\
\text { defines the role of the Authorizing Organization to } \\
\text { allocate sufficient resources to ensure safe, efficient, } \\
\text { and compliant operations. } \\
\text { CMELS-330 defines the roles of the CMELS } \\
\text { DAD/Ops to oversee and manage operations. The } \\
\text { AD Resource Manager ensures ES\&H needs are } \\
\text { incorporated into budgets and resource planning. }\end{array}$ \\
\hline
\end{tabular}

\footnotetext{
${ }^{1}$ Facility Management Chain/Program Management Chain
} 


\section{Conduct of Operations Applicability Matrix for Light Science \& Industry Facilities}

\begin{tabular}{|c|c|c|c|c|}
\hline $\begin{array}{l}\text { ES\&H MANUAL } \\
\text { DOCUMENT } 3.5 \\
\text { SECTION }\end{array}$ & $\begin{array}{c}\text { REQUISITES FOR SECTION } \\
\text { ELEMENTS }\end{array}$ & $\begin{array}{l}\text { APPLICABLE } \\
\text { YES/NO }\end{array}$ & $\begin{array}{c}\text { RESPONSIBILITY } \\
\text { FOR } \\
\text { COMPLIANCE } \\
\text { FMC/PMC }^{1}\end{array}$ & $\begin{array}{l}\text { COMMENTS AND/OR REFERENCE FOR } \\
\text { VERIFICATION OF COMPLIANCE }\end{array}$ \\
\hline & $\begin{array}{l}\text { Define organizational responsibilities } \\
\text { for both programmatic and support } \\
\text { organization personnel. }\end{array}$ & Yes & FMC/PMC & $\begin{array}{l}\text { CMELS-330 (Integrated Safety Management } \\
\text { System [ISMS]) and ES\&H Manual Document } 2.1 \\
\text { (General Worker Responsibilities and Integrated } \\
\text { Safety Management) describes organizational } \\
\text { responsibilities for programmatic and support } \\
\text { organizations. } \\
\text { This and all CMELS documents cited in this } \\
\text { worksheet can be found at the following URL: } \\
\text { http://sodium.IInl.gov/cmels/?url=library- } \\
\text { policies and procedures } \\
\text { CMELS Organization Chart - AD Office } \\
\text { http://sodium.IInl.gov/cmls/?url=library-organizations } \\
\text { AEED Organization Chart } \\
\text { http://sodium.IInl.gov/cmls/data/assets/images/org/a } \\
\text { eed/aeed orgcht.gif } \\
\text { BBTD Organization Chart } \\
\text { http://sodium.IInl.gov/cmls/data/assets/images/org/b } \\
\text { btd/bbtd orgcht.gif } \\
\text { CBD Organization Chart } \\
\underline{\text { http://sodium.IInl.gov/cmls/data/assets/images/org/c }} \\
\underline{\text { sd/csd orgcht.gif }} \\
\text { MSTD Organization Chart } \\
\text { http://sodium.IInl.gov/cmls/data/assets/images/org/m } \\
\text { std/mstd orgcht.gif }\end{array}$ \\
\hline
\end{tabular}




\section{Conduct of Operations Applicability Matrix for Light Science \& Industry Facilities}

\begin{tabular}{|c|c|c|c|c|}
\hline $\begin{array}{l}\text { ES\&H MANUAL } \\
\text { DOCUMENT } 3.5 \\
\text { SECTION }\end{array}$ & $\begin{array}{l}\text { REQUISITES FOR SECTION } \\
\text { ELEMENTS }\end{array}$ & $\begin{array}{l}\text { APPLICABLE } \\
\text { YES/NO }\end{array}$ & $\begin{array}{c}\text { RESPONSIBILITY } \\
\text { FOR } \\
\text { COMPLIANCE } \\
\text { FMC/PMC }^{1}\end{array}$ & $\begin{array}{l}\text { COMMENTS AND/OR REFERENCE FOR } \\
\text { VERIFICATION OF COMPLIANCE }\end{array}$ \\
\hline & $\begin{array}{l}\text { Identify the individual responsible for } \\
\text { implementing the ES\&H controls in } \\
\text { the FSP or IWS/SP. }\end{array}$ & Yes & FMC/PMC & $\begin{array}{l}\text { CMELS-330 and ES\&H Manual Document } 2.1 \\
\text { defines roles, responsibilities, and authorities. } \\
\text { Responsibilities by role are also defined in CMELS } \\
\text { Facility Safety Plans (FSPs) } 411 \& 412 \text {. For } \\
\text { IWS/SPs (formerly OSPs), the responsible } \\
\text { individuals are specifically named. }\end{array}$ \\
\hline \multirow[t]{3}{*}{$\begin{array}{l}\text { 1.2.3. Monitoring of } \\
\text { Operating } \\
\text { Performance }\end{array}$} & $\begin{array}{l}\text { Operating and safety goals should be } \\
\text { established. }\end{array}$ & Yes & FMC/PMC & $\begin{array}{l}\text { CMELS-330 establishes commitments and metrics } \\
\text { for meeting LLNL safety goals, performance } \\
\text { measures, and the success of the ISMS. CMELS- } \\
330 \text { assigns responsibility to the Authorizing } \\
\text { Organization to define technical objectives of the } \\
\text { work activity. Programmatic goals are defined by } \\
\text { each program (in each Work request). }\end{array}$ \\
\hline & $\begin{array}{l}\text { Work supervisors or their designees } \\
\text { should regularly observe important } \\
\text { operational activities to identify and } \\
\text { correct safety and operating } \\
\text { deficiencies. }\end{array}$ & Yes & FMC/PMC & $\begin{array}{l}\text { CMLS-305 (ES\&H Self-Assessment Plan) specifies } \\
\text { schedules and requirements for self-assessments. } \\
\text { CMELS senior management, Division management, } \\
\text { and Work Supervisors routinely observe operations } \\
\text { in walk-arounds. } \\
\text { ES\&H Manual, Document 2.1, General Worker } \\
\text { Responsibilities and Integrated Safety Management. }\end{array}$ \\
\hline & $\begin{array}{l}\text { Document and evaluate operating } \\
\text { problems and develop corrective } \\
\text { actions to improve performance. }\end{array}$ & Yes & FMC/PMC & $\begin{array}{l}\text { CMELS-330 defines provisions for } \\
\text { reviewing/analyzing safety data within the } \\
\text { Directorate. CMLS- } 305 \text { defines provisions for rolling } \\
\text { up data to the Institutional level for trending. } \\
\text { The CMELS Assurance Office also conducts an } \\
\text { annual assessment, which reports on trends within } \\
\text { the directorate. }\end{array}$ \\
\hline
\end{tabular}




\section{Conduct of Operations Applicability Matrix for Light Science \& Industry Facilities}

\begin{tabular}{|c|c|c|c|c|}
\hline $\begin{array}{l}\text { ES\&H MANUAL } \\
\text { DOCUMENT } 3.5 \\
\text { SECTION }\end{array}$ & $\begin{array}{l}\text { REQUISITES FOR SECTION } \\
\text { ELEMENTS }\end{array}$ & $\begin{array}{l}\text { APPLICABLE } \\
\text { YES/NO }\end{array}$ & $\begin{array}{c}\text { RESPONSIBILITY } \\
\text { FOR } \\
\text { COMPLIANCE } \\
\text { FMC/PMC }^{1} \\
\end{array}$ & $\begin{array}{l}\text { COMMENTS AND/OR REFERENCE FOR } \\
\text { VERIFICATION OF COMPLIANCE }\end{array}$ \\
\hline \multirow[t]{2}{*}{ 1.2.4. Accountability } & $\begin{array}{l}\text { Written performance appraisals } \\
\text { should provide feedback to workers } \\
\text { about their safety and job } \\
\text { performance. }\end{array}$ & Yes & FMC/PMC & $\begin{array}{l}\text { CMELS- } 330 \text { establishes requirements to ensure } \\
\text { safety accountability is part of the performance } \\
\text { appraisal process. CMELS-104 (Performance } \\
\text { Appraisal, Ranking, and Salary Policy) requires that } \\
\text { the Performance Appraisal include information on } \\
\text { ES\&H responsibilities and expectations, and that } \\
\text { employees be appraised on the performance of } \\
\text { those responsibilities. }\end{array}$ \\
\hline & $\begin{array}{l}\text { Formal performance appraisals } \\
\text { should be provided at least annually } \\
\text { and should document operational } \\
\text { performance. }\end{array}$ & Yes & FMC/PMC & $\begin{array}{l}\text { CMELS- } 330 \text { establishes requirements to ensure } \\
\text { safety accountability is part of the performance } \\
\text { appraisal process. CMELS-104 (Performance } \\
\text { Appraisal, Ranking, and Salary Policy) requires that } \\
\text { the Performance Appraisal include information on } \\
\text { ES\&H responsibilities and expectations, and that } \\
\text { employees be appraised on the performance of } \\
\text { those responsibilities. }\end{array}$ \\
\hline $\begin{array}{l}\text { 1.2.5. Management } \\
\text { Training }\end{array}$ & $\begin{array}{l}\text { Managers (NF/HHF/MHF) and work } \\
\text { supervisors (ALL) should receive } \\
\text { training in supervisory skills, ES\&H } \\
\text { issues specific to the facility, and } \\
\text { facility operations in their area of } \\
\text { responsibility. }\end{array}$ & Yes & FMC/PMC & $\begin{array}{l}\text { CMELS-330 \& ES\&H Manual Document } 2.1 \\
\text { establish Authorizing Organization/Individual } \\
\text { responsibilities to include designating an appropriate } \\
\text { RI and to provide support to that RI and to ensure } \\
\text { that individuals conducting the work possess the } \\
\text { necessary skills, knowledge, and abilities (SKA). } \\
\text { CMELS-330 assigns training responsibilities to the } \\
\text { CMELS DAD/Ops to manage the CMELS Training } \\
\text { Program and assigns responsibilities to Payroll } \\
\text { Supervisors to develop personnel skills to ensure } \\
\text { necessary SKAs. The Payroll Supervisors also } \\
\text { ensure accuracy of the LTRAIN Questionnaire to } \\
\text { develop LTRAIN profiles to identify Institutional and } \\
\text { Organizational Training Requirements for managers } \\
\text { and supervisors, and use LTRAIN to track } \\
\text { completion of those courses. }\end{array}$ \\
\hline
\end{tabular}




\section{Conduct of Operations Applicability Matrix for Light Science \& Industry Facilities}

\begin{tabular}{|c|c|c|c|c|}
\hline $\begin{array}{l}\text { ES\&H MANUAL } \\
\text { DOCUMENT } 3.5 \\
\text { SECTION }\end{array}$ & $\begin{array}{l}\text { REQUISITES FOR SECTION } \\
\text { ELEMENTS }\end{array}$ & $\begin{array}{l}\text { APPLICABLE } \\
\text { YES/NO }\end{array}$ & $\begin{array}{c}\text { RESPONSIBILITY } \\
\text { FOR } \\
\text { COMPLIANCE } \\
\text { FMC/PMC }^{1} \\
\end{array}$ & $\begin{array}{l}\text { COMMENTS AND/OR REFERENCE FOR } \\
\text { VERIFICATION OF COMPLIANCE }\end{array}$ \\
\hline $\begin{array}{l}\text { 1.2.6. Planning for } \\
\text { Safety }\end{array}$ & $\begin{array}{l}\text { Safety preplanning and review } \\
\text { process for routine work and new } \\
\text { processes or experiments should be } \\
\text { documented. }\end{array}$ & Yes & FMC/PMC & $\begin{array}{l}\text { CMELS- } 330 \text { and ES\&H Manual Document } 2.1 \\
\text { establishes the Integration Work Sheet (IWS) } \\
\text { process to review new work activities not commonly } \\
\text { performed by the public and to set requirements to } \\
\text { ensure operations are within the safety basis } \\
\text { envelope of each facility. }\end{array}$ \\
\hline \multicolumn{5}{|l|}{$\begin{array}{c}\text { SHIFT ROUTINES } \\
\text { AND OPERATING } \\
\text { PRACTICES } \\
\text { SECTION } 2.0 \\
\end{array}$} \\
\hline \multirow[t]{2}{*}{$\begin{array}{l}\text { 2.2.1. Status } \\
\text { Practices }\end{array}$} & $\begin{array}{l}\text { Responsible operators/workers } \\
\text { should be promptly notified of } \\
\text { changes in equipment or system } \\
\text { status. }\end{array}$ & Yes & FMC/PMC & $\begin{array}{l}\text { CMELS S200 LSI facilities do not utilize multiple } \\
\text { shifts. Equipment or systems for which prompt } \\
\text { notification of status change is required are } \\
\text { identified in IWSs. The methods of notification are } \\
\text { defined in these documents. }\end{array}$ \\
\hline & $\begin{array}{l}\text { Operators/workers should be } \\
\text { instructed to promptly notify the facility } \\
\text { and/or program management chain } \\
\text { (as appropriate) of abnormalities; } \\
\text { abnormal, unusual or emergency } \\
\text { events; changes in operational status; } \\
\text { significant changes in schedules; and } \\
\text { difficulties encountered in performing } \\
\text { tasks. }\end{array}$ & Yes & FMC/PMC & $\begin{array}{l}\text { CMELS-330 defines the occurrence reporting } \\
\text { process for CMELS. FSPs also refer to the } \\
\text { processes defined in CMELS-330. } \\
\text { CMELS-330 discusses CMELS emergency } \\
\text { response plans and processes. FSPs } 411 \& 412 \\
\text { also contain information on how to respond to } \\
\text { emergencies. } \\
\text { CMLS-409 (Site } 200 \text { Employee Emergency } \\
\text { Response Self-Help Guide) (hard copies of this } \\
\text { document are available in all laboratories and } \\
\text { offices) also provides guidance to employees on } \\
\text { reporting unexpected events and unknowns. }\end{array}$ \\
\hline $\begin{array}{l}\text { 2.2.2. Safety } \\
\text { Practices }\end{array}$ & Develop safety plans. & Yes & FMC/PMC & $\begin{array}{l}\text { CMELS-330 and ES\&H Manual Document 3.3, } \\
\text { "Facility Safety Plans and Integration Work Sheets } \\
\text { with Safety Plans," implement the requirements to } \\
\text { prepare FSPs and IWS/SPs. } \\
\text { FSPs } 411 \& 412 \text { also provide guidance for when } \\
\text { IWS/SPs are required. } \\
\text { ES\&H Manual, Document 2.2, Managing ES\&H for } \\
\text { LLNL Work. }\end{array}$ \\
\hline
\end{tabular}




\section{Conduct of Operations Applicability Matrix for Light Science \& Industry Facilities}

\begin{tabular}{|c|c|c|c|c|}
\hline $\begin{array}{l}\text { ES\&H MANUAL } \\
\text { DOCUMENT } 3.5 \\
\text { SECTION }\end{array}$ & $\begin{array}{c}\text { REQUISITES FOR SECTION } \\
\text { ELEMENTS }\end{array}$ & $\begin{array}{l}\text { APPLICABLE } \\
\text { YES/NO }\end{array}$ & $\begin{array}{l}\text { RESPONSIBILITY } \\
\text { FOR } \\
\text { COMPLIANCE } \\
\text { FMC/PMC }^{1} \\
\end{array}$ & $\begin{array}{l}\text { COMMENTS AND/OR REFERENCE FOR } \\
\text { VERIFICATION OF COMPLIANCE }\end{array}$ \\
\hline & $\begin{array}{l}\text { Workers are trained to properly } \\
\text { operate equipment and understand } \\
\text { the safety plans. }\end{array}$ & Yes & FMC/PMC & $\begin{array}{l}\text { CMELS-330 and ES\&H Manual Document } 2.1 \\
\text { directs the RI to ensure worker qualifications } \\
\text { including an understanding of the FSP and IWS/SP. } \\
\text { FSPs } 411 \text { \& } 412 \text { describe appropriate responses to } \\
\text { facility emergencies. Facility management provides } \\
\text { FSP briefings to facility residents via BR2201 } \\
\text { (Facility Safety Plan Training for Biological Facilities) } \\
\text { and documents this in LTRAIN. } \\
\text { Formal training is documented and verified through } \\
\text { LTRAIN. } \\
\text { ES\&H Manual, Document 22.1, Emergency } \\
\text { Preparedness and Response. }\end{array}$ \\
\hline & $\begin{array}{l}\text { Adhere to requirements in the } \\
\text { Industrial safety program. }\end{array}$ & Yes & FMC/PMC & $\begin{array}{l}\text { The Industrial Safety (IS) Program is documented in } \\
\text { the IS Discipline Action Plans (DAP) maintained by } \\
\text { ES\&H Teams } 2 \text { (Site 200), which captures the } \\
\text { requirements of the ES\&H Manual. } \\
\text { ES\&H Manual, Documents } 11.1,11.2,15.2,16.1 \text {, } \\
17.1,18.1,18.5,22.4 \text {. and } 42.1 .\end{array}$ \\
\hline & $\begin{array}{l}\text { Adhere to requirements in the Health } \\
\text { physics program. }\end{array}$ & Yes & FMC/PMC & $\begin{array}{l}\text { The Health Physics (HP) Program is documented in } \\
\text { the HP DAP maintained by ES\&H Teams } 2 \text { (Site } \\
\text { 200), which captures the requirements of the ES\&H } \\
\text { Manual. }\end{array}$ \\
\hline & $\begin{array}{l}\text { Adhere to requirements in the } \\
\text { Industrial hygiene program. }\end{array}$ & Yes & FMC/PMC & $\begin{array}{l}\text { The Industrial Hygiene (IH) Program is documented } \\
\text { in the IH DAP maintained by ES\&H Teams } 2 \text { (Site } \\
200) \text {, which captures the requirements of the ES\&H } \\
\text { Manual. } \\
\text { ES\&H Manual, Documents } 11.1,11.2,12.2,13.1 \text {, } \\
\text { and } 14.1 \text {. }\end{array}$ \\
\hline
\end{tabular}




\section{Conduct of Operations Applicability Matrix for Light Science \& Industry Facilities}

\begin{tabular}{|c|c|c|c|c|}
\hline $\begin{array}{l}\text { ES\&H MANUAL } \\
\text { DOCUMENT } 3.5 \\
\text { SECTION }\end{array}$ & $\begin{array}{l}\text { REQUISITES FOR SECTION } \\
\text { ELEMENTS }\end{array}$ & $\begin{array}{l}\text { APPLICABLE } \\
\text { YES/NO }\end{array}$ & $\begin{array}{l}\text { RESPONSIBILITY } \\
\text { FOR } \\
\text { COMPLIANCE } \\
\text { FMC/PMC }^{1} \\
\end{array}$ & $\begin{array}{l}\text { COMMENTS AND/OR REFERENCE FOR } \\
\text { VERIFICATION OF COMPLIANCE }\end{array}$ \\
\hline & $\begin{array}{l}\text { Adhere to requirements in the } \\
\text { Criticality safety program. }\end{array}$ & Yes & FMC/PMC & $\begin{array}{l}\text { The Criticality Safety Program is documented in the } \\
\text { Criticality DAP maintained by ES\&H Team 2, which } \\
\text { captures the requirements of the ES\&H Manual, } \\
\text { Document } 20.6 \text {, Criticality Safety. In addition, the } \\
\text { Criticality Safety Section of the Hazards Control } \\
\text { Department reviews activities involving the potential } \\
\text { for nuclear criticality at the request the Health } \\
\text { Physicist or Facility Management. }\end{array}$ \\
\hline & $\begin{array}{l}\text { Adhere to requirements in the Fire } \\
\text { safety program. }\end{array}$ & Yes & FMC/PMC & $\begin{array}{l}\text { The Fire Safety (FS) Program is documented in the } \\
\text { Fire Protection DAP maintained by ES\&H Teams } 2 \\
\text { (Site 200, which captures the requirements of the } \\
\text { ES\&H Manual, Document 22.5, Fire. }\end{array}$ \\
\hline & $\begin{array}{l}\text { Adhere to requirements in the } \\
\text { Environmental protection program. }\end{array}$ & Yes & FMC/PMC & $\begin{array}{l}\text { The Environmental Protection Program is } \\
\text { documented in the Environmental Protection DAP } \\
\text { maintained by ES\&H Teams } 2 \text { (Site 200), which } \\
\text { captures the requirements of the ES\&H Manual. The } \\
\text { electronic IWS system documents NEPA and other } \\
\text { environmental reviews. More information regarding } \\
\text { the environmental protection program can be found } \\
\text { in Volume II of the ES\&H Manual, Document } 30.1 \text {. }\end{array}$ \\
\hline & $\begin{array}{l}\text { Adhere to requirements in the ALARA } \\
\text { program. }\end{array}$ & Yes & FMC/PMC & $\begin{array}{l}\text { CMELS Site } 200 \text { facilities do not require a formal } \\
\text { ALARA program in accordance with the LLNL ES\&H } \\
\text { Manual Document } 20.4 \text { (“LLNL Occupational } \\
\text { Radiation Protection ALARA Program") since } \\
\text { individual occupational radiation doses in the facility } \\
\text { are not likely to exceed 100mrem/year. However, } \\
\text { FSPs } 411 \& 412 \text { stress ALARA goals, and CMELS- } \\
330 \text { requires RIs to integrate ALARA philosophy into } \\
\text { operations. }\end{array}$ \\
\hline $\begin{array}{l}\text { 2.2.3. Operator } \\
\text { Inspection Tours }\end{array}$ & $\begin{array}{l}\text { Procedures for Operator/FC tours } \\
\text { should follow the guidance in Section } \\
2.2 .3 \text {. }\end{array}$ & No & NA & $\begin{array}{l}\text { Daily shift tours are not utilized in CMELS S200 LSI } \\
\text { facilities due to the low anticipated consequences of } \\
\text { delayed discovery of abnormal conditions. }\end{array}$ \\
\hline
\end{tabular}




\section{Conduct of Operations Applicability Matrix for Light Science \& Industry Facilities}

\begin{tabular}{|c|c|c|c|c|}
\hline $\begin{array}{l}\text { ES\&H MANUAL } \\
\text { DOCUMENT } 3.5 \\
\text { SECTION }\end{array}$ & $\begin{array}{l}\text { REQUISITES FOR SECTION } \\
\text { ELEMENTS }\end{array}$ & $\begin{array}{l}\text { APPLICABLE } \\
\text { YES/NO }\end{array}$ & $\begin{array}{l}\text { RESPONSIBILITY } \\
\text { FOR } \\
\text { COMPLIANCE } \\
\text { FMC/PMC }^{1} \\
\end{array}$ & $\begin{array}{l}\text { COMMENTS AND/OR REFERENCE FOR } \\
\text { VERIFICATION OF COMPLIANCE }\end{array}$ \\
\hline $\begin{array}{l}\text { 2.2.4. Round/Tour } \\
\text { Inspection Sheets }\end{array}$ & $\begin{array}{l}\text { Procedures for Round/Tour Inspection } \\
\text { Sheets should follow the guidance in } \\
\text { Section 2.2.4. }\end{array}$ & No & NA & $\begin{array}{l}\text { Daily shift tours are not utilized in CMELS S200 LSI } \\
\text { facilities due to the low anticipated consequences of } \\
\text { delayed discovery of abnormal conditions. }\end{array}$ \\
\hline \multirow[t]{2}{*}{$\begin{array}{l}\text { 2.2.5. Personnel } \\
\text { Protection }\end{array}$} & $\begin{array}{l}\text { In addition to the discussion in } \\
\text { Section 2.2.2 (Safety Practices), } \\
\text { applicable personnel } \\
\text { training/qualification should include } \\
\text { the guidance in Section 2.2.5. }\end{array}$ & Yes & FMC/PMC & $\begin{array}{l}\text { Operations personnel are trained to understand and } \\
\text { comply with all area postings for exposure warnings } \\
\text { and PPE requirements. }\end{array}$ \\
\hline & $\begin{array}{l}\text { Supervisors should review exposure } \\
\text { trends. }\end{array}$ & Yes & FMC/PMC & $\begin{array}{l}\text { Document 20.4, "LLNL Occupational Radiation } \\
\text { Protection ALARA Program," requires ES\&H Team } \\
\text { Health Physicists submittal of notable trends or } \\
\text { ALARA issues to facility and program management } \\
\text { when facilities have established ALARA goals. }\end{array}$ \\
\hline $\begin{array}{l}\text { 2.2.6. Response to } \\
\text { Indications }\end{array}$ & $\begin{array}{l}\text { Response to Indications should follow } \\
\text { the guidance in Section 2.2.6. }\end{array}$ & Yes & FMC/PMC & $\begin{array}{l}\text { Indicators important to the safe operation of systems } \\
\text { and the desired response to abnormal readings are } \\
\text { identified in applicable safety plans. }\end{array}$ \\
\hline $\begin{array}{l}\text { 2.2.7. Resetting } \\
\text { Protective Devices }\end{array}$ & $\begin{array}{l}\text { Establish controls for resetting } \\
\text { protective devices whose improper } \\
\text { positioning/ operation could result in } \\
\text { an impact to health, safety, the } \\
\text { environment,. }\end{array}$ & Yes & FMC/PMC & $\begin{array}{l}\text { Protective devices (other than circuit breakers, } \\
\text { GFCls, and fuses) and the appropriate response to } \\
\text { a trip condition are identified in applicable safety } \\
\text { plans. Section } 8.2 \text { of ES\&H Manual Document } 16.1 \\
\text { "Electrical Safety Program" recommends } \\
\text { supplemental training for workers who reset } \\
\text { overcurrent protective devices. }\end{array}$ \\
\hline 2.2.8. Load Changes & $\begin{array}{l}\text { Establish that load changes have } \\
\text { been addressed. }\end{array}$ & No & NA & $\begin{array}{l}\text { This attribute is not applicable (i.e., these facilities } \\
\text { do not perform load changes). }\end{array}$ \\
\hline $\begin{array}{l}\text { 2.2.9. Authority to } \\
\text { Operate Equipment }\end{array}$ & $\begin{array}{l}\text { Identify personnel authorized to } \\
\text { operate facility equipment whose } \\
\text { improper operation could result in an } \\
\text { impact to health, safety, the } \\
\text { environment. }\end{array}$ & Yes & FMC & $\begin{array}{l}\text { Operation of all Plant Equipment (regardless of } \\
\text { impact) requires approval of Facility Point of } \\
\text { Contact. RHWM personnel are approved to operate } \\
\text { non-hazardous wastewater retention systems } \\
\text { according to documented operating procedures. }\end{array}$ \\
\hline
\end{tabular}




\section{Conduct of Operations Applicability Matrix for Light Science \& Industry Facilities}

\begin{tabular}{|c|c|c|c|c|}
\hline $\begin{array}{l}\text { ES\&H MANUAL } \\
\text { DOCUMENT } 3.5 \\
\text { SECTION }\end{array}$ & $\begin{array}{l}\text { REQUISITES FOR SECTION } \\
\text { ELEMENTS }\end{array}$ & $\begin{array}{l}\text { APPLICABLE } \\
\text { YES/NO }\end{array}$ & $\begin{array}{c}\text { RESPONSIBILITY } \\
\text { FOR } \\
\text { COMPLIANCE } \\
\text { FMC/PMC }^{1} \\
\end{array}$ & $\begin{array}{l}\text { COMMENTS AND/OR REFERENCE FOR } \\
\text { VERIFICATION OF COMPLIANCE }\end{array}$ \\
\hline $\begin{array}{l}\text { 2.2.10. Shift } \\
\text { Operating Bases }\end{array}$ & $\begin{array}{l}\text { Establish shift operating bases for } \\
\text { each shift position. }\end{array}$ & No & NA & $\begin{array}{l}\text { Facilities don't contain operations or equipment that } \\
\text { warrant designation of a shift operating base. }\end{array}$ \\
\hline $\begin{array}{l}\text { 2.2.11. Potentially } \\
\text { Distractive Written } \\
\text { Material and Devices }\end{array}$ & $\begin{array}{l}\text { Identify controls for Potentially } \\
\text { Distractive Written Material and } \\
\text { Devices. }\end{array}$ & No & NA & $\begin{array}{l}\text { Facilities don't contain operations or equipment that } \\
\text { could result in significant impact to ES\&H or } \\
\text { programs that warrant these controls. }\end{array}$ \\
\hline \multicolumn{5}{|l|}{$\begin{array}{l}\text { CONTROL AREA } \\
\text { ACTIVITIES FOR } \\
\text { DOE FACILITIES } \\
\text { SECTION } 3.0 \\
\end{array}$} \\
\hline \multirow[t]{2}{*}{$\begin{array}{l}\text { 3.2.1. Control Area } \\
\text { Access }\end{array}$} & $\begin{array}{l}\text { Control rooms associated with } \\
\text { systems, equipment or processes } \\
\text { where operator error could result in } \\
\text { significant impact to health, safety, the } \\
\text { environment or to programs are } \\
\text { identified and physically delineated. }\end{array}$ & No & NA & These facilities do not have Control Rooms. \\
\hline & $\begin{array}{l}\text { Specify personnel who are authorized } \\
\text { for access to control rooms }\end{array}$ & No & NA & These facilities do not have Control Rooms. \\
\hline $\begin{array}{l}\text { 3.2.2. Professional } \\
\text { behavior }\end{array}$ & $\begin{array}{l}\text { Control room activities are limited to } \\
\text { those essential for supporting } \\
\text { operations. }\end{array}$ & No & NA & These facilities do not have Control Rooms. \\
\hline $\begin{array}{l}\text { 3.2.3. Monitoring the } \\
\text { Main Control Panels }\end{array}$ & $\begin{array}{l}\text { Responsible operators should } \\
\text { understand their responsibility for } \\
\text { monitoring control room panels, } \\
\text { including timely response to alarm } \\
\text { conditions. }\end{array}$ & No & NA & These facilities do not have Control Rooms. \\
\hline $\begin{array}{l}\text { 3.2.4. Control } \\
\text { Operator Ancillary } \\
\text { Duties }\end{array}$ & $\begin{array}{l}\text { Ancillary duties should not interfere } \\
\text { with the operators' shift } \\
\text { responsibilities. }\end{array}$ & No & NA & These facilities do not have Control Rooms. \\
\hline
\end{tabular}




\section{Conduct of Operations Applicability Matrix for Light Science \& Industry Facilities}

\begin{tabular}{|c|c|c|c|c|}
\hline $\begin{array}{l}\text { ES\&H MANUAL } \\
\text { DOCUMENT } 3.5 \\
\text { SECTION }\end{array}$ & $\begin{array}{l}\text { REQUISITES FOR SECTION } \\
\text { ELEMENTS }\end{array}$ & $\begin{array}{l}\text { APPLICABLE } \\
\text { YES/NO }\end{array}$ & $\begin{array}{l}\text { RESPONSIBILITY } \\
\text { FOR } \\
\text { COMPLIANCE } \\
\text { FMC/PMC }^{1} \\
\end{array}$ & $\begin{array}{l}\text { COMMENTS AND/OR REFERENCE FOR } \\
\text { VERIFICATION OF COMPLIANCE }\end{array}$ \\
\hline $\begin{array}{l}\text { 3.2.5. Operation of } \\
\text { Control Area } \\
\text { Equipment }\end{array}$ & $\begin{array}{l}\text { Only authorized personnel shall } \\
\text { operate control area equipment. }\end{array}$ & No & NA & These facilities do not have Control Rooms. \\
\hline \multicolumn{5}{|l|}{$\begin{array}{l}\text { COMMUNICATIONS } \\
\text { SECTION } 4.0\end{array}$} \\
\hline \multirow[t]{2}{*}{$\begin{array}{l}\text { 4.2.1. Emergency } \\
\text { Communications } \\
\text { Systems }\end{array}$} & $\begin{array}{l}\text { Ensure ready notification of workers } \\
\text { during routine and emergency } \\
\text { conditions. }\end{array}$ & Yes & FMC & $\begin{array}{l}\text { Building intercom, emergency paging system, } \\
\text { postings on equipment or facility entrances, or } \\
\text { emergency bullhorns are available. An emergency } \\
\text { call list is maintained by Fire Dispatch and updated } \\
\text { by the building H\&S Technicians. } \\
\text { Document 22.1, Emergency Preparedness and } \\
\text { Response. }\end{array}$ \\
\hline & $\begin{array}{l}\text { Emergency communications are } \\
\text { regularly tested for functionality. }\end{array}$ & Yes & FMC/PMC & $\begin{array}{l}\text { Plant Engineering conducts routine PM and testing } \\
\text { of alarm systems. } \\
\text { LLNL Site emergency communications systems are } \\
\text { tested daily by the LLNL Alarms Division (Facility } \\
\text { Management should ensure that emergency } \\
\text { communications can be heard in the facility). }\end{array}$ \\
\hline $\begin{array}{l}\text { 4.2.2. Public Address } \\
\text { System }\end{array}$ & $\begin{array}{l}\text { Public Address system is } \\
\text { administratively controlled. }\end{array}$ & Yes & $\mathrm{FMC/PMC}$ & $\begin{array}{l}\text { LLNL Alarms Division controls the Site emergency } \\
\text { communication system. }\end{array}$ \\
\hline \multirow[t]{2}{*}{$\begin{array}{l}\text { 4.2.3. Contacting } \\
\text { Operators }\end{array}$} & $\begin{array}{l}\text { Provide functional communication } \\
\text { devices (telephones, paging systems) } \\
\text { within the facility and immediate area. }\end{array}$ & Yes & FMC & $\begin{array}{l}\text { Telephones throughout occupied facilities, } \\
\text { emergency paging system, radio pagers, two-way } \\
\text { radios for facility operations staff and electronic mail } \\
\text { provide rapid communications. }\end{array}$ \\
\hline & $\begin{array}{l}\text { Provide safety alarms. Visual alarms } \\
\text { should be used in noisy areas where } \\
\text { audible alarms may go unnoticed. }\end{array}$ & Yes & FMC & $\begin{array}{l}\text { Malfunctions of the telephones, building paging } \\
\text { system, pagers, and electronic mail are infrequent. } \\
\text { Telephone, alarms, and radio page systems have } \\
\text { either battery or stand-by generator power. } \\
\text { ES\&H Manual, Document } 12.1 \text {. }\end{array}$ \\
\hline
\end{tabular}




\section{Conduct of Operations Applicability Matrix for Light Science \& Industry Facilities}

\begin{tabular}{|c|c|c|c|c|}
\hline $\begin{array}{l}\text { ES\&H MANUAL } \\
\text { DOCUMENT } 3.5 \\
\text { SECTION }\end{array}$ & $\begin{array}{l}\text { REQUISITES FOR SECTION } \\
\text { ELEMENTS }\end{array}$ & $\begin{array}{l}\text { APPLICABLE } \\
\text { YES/NO }\end{array}$ & $\begin{array}{l}\text { RESPONSIBILITY } \\
\text { FOR } \\
\text { COMPLIANCE } \\
\text { FMC/PMC }^{1} \\
\end{array}$ & $\begin{array}{l}\text { COMMENTS AND/OR REFERENCE FOR } \\
\text { VERIFICATION OF COMPLIANCE }\end{array}$ \\
\hline & $\begin{array}{l}\text { Communication systems should be } \\
\text { available in remote areas where work } \\
\text { is conducted, such as basements, } \\
\text { lofts, and equipment rooms. }\end{array}$ & Yes & FMC & $\begin{array}{l}\text { Building intercom and radio page provide coverage } \\
\text { in out-of the-way portions of the facilities. }\end{array}$ \\
\hline & $\begin{array}{l}\text { As appropriate, provisions should } \\
\text { exist for locating key workers during } \\
\text { off-hours, and during the workday } \\
\text { while they are outside the facility. }\end{array}$ & Yes & FMC/PMC & $\begin{array}{l}\text { Key operational personnel can be reached via radio } \\
\text { pager and government-owned cellular telephone } \\
\text { systems. Lists of emergency contact numbers are } \\
\text { maintained by the CMELS payroll organizations. }\end{array}$ \\
\hline 4.2.4. Radios & $\begin{array}{l}\text { Areas where radios are prohibited } \\
\text { should be delineated. }\end{array}$ & Yes & FMC/PMC & Areas where radios are prohibited are posted. \\
\hline $\begin{array}{l}\text { 4.2.5. Abbreviations } \\
\text { and Acronyms }\end{array}$ & $\begin{array}{l}\text { In emergency communications, limit } \\
\text { use of abbreviations and acronyms to } \\
\text { those in approved LLNL documents. }\end{array}$ & Yes & FMC/PMC & $\begin{array}{l}\text { LLNL Alarms Division controls the Site emergency } \\
\text { communication system and as a general rule do not } \\
\text { use acronyms in emergency communications. }\end{array}$ \\
\hline $\begin{array}{l}\text { 4.2.6. Oral } \\
\text { instructions and } \\
\text { Informal } \\
\text { Communications }\end{array}$ & $\begin{array}{l}\text { Oral Instructions and Informational } \\
\text { Communications should follow the } \\
\text { guidance in Section 4.2.6. }\end{array}$ & Yes & FMC/PMC & $\begin{array}{l}\text { Oral instructions involving equipment operations } \\
\text { should be clear and concise. }\end{array}$ \\
\hline \multicolumn{5}{|l|}{$\begin{array}{l}\text { CONTROL OF ON- } \\
\text { SHIFT TRAINING } \\
\text { SECTION } 5.0\end{array}$} \\
\hline $\begin{array}{l}\text { 5.2.1. Adherence to } \\
\text { Training Programs }\end{array}$ & Identify tasks requiring OJT. & Yes & PMC & $\begin{array}{l}\text { OJT requirements are identified in Document } 40.1 \text {, } \\
\text { "LLNL Training Program Manual," and CMELS- } 330 \text {. } \\
\text { CMELS- } 330 \text { requires the RI to ensure required } \\
\text { training, including on-the-job training (OJT), is } \\
\text { completed and to ensure workers have necessary } \\
\text { qualifications. }\end{array}$ \\
\hline
\end{tabular}




\section{Conduct of Operations Applicability Matrix for Light Science \& Industry Facilities}

\begin{tabular}{|c|c|c|c|c|}
\hline $\begin{array}{l}\text { ES\&H MANUAL } \\
\text { DOCUMENT } 3.5 \\
\text { SECTION }\end{array}$ & $\begin{array}{l}\text { REQUISITES FOR SECTION } \\
\text { ELEMENTS }\end{array}$ & $\begin{array}{l}\text { APPLICABLE } \\
\text { YES/NO }\end{array}$ & $\begin{array}{c}\text { RESPONSIBILITY } \\
\text { FOR } \\
\text { COMPLIANCE } \\
\text { FMC/PMC }^{1} \\
\end{array}$ & $\begin{array}{l}\text { COMMENTS AND/OR REFERENCE FOR } \\
\text { VERIFICATION OF COMPLIANCE }\end{array}$ \\
\hline $\begin{array}{l}\text { 5.2.2. On-shift } \\
\text { Instructor } \\
\text { Qualifications }\end{array}$ & $\begin{array}{l}\text { Document instructor and evaluator } \\
\text { qualifications. }\end{array}$ & Yes & PMC & $\begin{array}{l}\text { Qualifications for OJT training instructors are } \\
\text { determined by education, experience, background, } \\
\text { subject area knowledge, and the ability to instruct } \\
\text { others. Al and RI specify individuals authorized to } \\
\text { conduct OJT for specific facilities, equipment, or } \\
\text { operations. Completions of formal degree programs } \\
\text { are documented in personnel records. Completions } \\
\text { of classes during LLNL employment are recorded in } \\
\text { LTRAIN. } \\
\text { ES\&H Manual Document } 40.1 \text {. }\end{array}$ \\
\hline \multirow[t]{2}{*}{$\begin{array}{l}\text { 5.2.3. Qualified } \\
\text { Operator Supervision } \\
\text { and Control of } \\
\text { Trainees }\end{array}$} & $\begin{array}{l}\text { Establish protocol for supervision and } \\
\text { control of trainees. }\end{array}$ & Yes & PMC & $\begin{array}{l}\text { FSPs, IWS/SPs, and/or IWSs define (as } \\
\text { appropriate) conditions under which trainees may be } \\
\text { used to support potentially hazardous work } \\
\text { activities. The IWS lists names of qualified } \\
\text { personnel to do the work activity. }\end{array}$ \\
\hline & $\begin{array}{l}\text { Ensure trainee awareness of hazards } \\
\text { and operating limits. }\end{array}$ & Yes & PMC & $\begin{array}{l}\text { CMELS- } 330 \text { requires the RI to ensure that trainees } \\
\text { only work according to existing procedures and } \\
\text { IWSs, and that they are aware of operating limits } \\
\text { and hazards. CMELS- } 330 \text { requires the RI to ensure } \\
\text { visitors, guests, students, and vendors either have } \\
\text { the required training or work under the direct } \\
\text { supervision of a qualified worker. }\end{array}$ \\
\hline $\begin{array}{l}\text { 5.2.4. Operator } \\
\text { Qualification Program } \\
\text { Approval }\end{array}$ & $\begin{array}{l}\text { Ensure the appropriate area } \\
\text { supervisor has approved the OJT. }\end{array}$ & Yes & PMC & $\begin{array}{l}\text { The RI documents and then either provides or } \\
\text { approves OJT for personnel working under their } \\
\text { direction. This process is reflected in the IWS } \\
\text { authorizing the work. } \\
\text { Formal OJT programs may substitute for the RI } \\
\text { documentation. }\end{array}$ \\
\hline $\begin{array}{l}\text { 5.2.5. Training } \\
\text { Documentation }\end{array}$ & Document OJT. & Yes & PMC & $\begin{array}{l}\text { OJT training is documented in the Training } \\
\text { Qualification Record maintained by the payroll } \\
\text { supervisor in accordance with Document } 40.1, \\
\text { "LLNL Training Program Manual." CMELS- } 330 \\
\text { defines record keeping requirements for training } \\
\text { records. }\end{array}$ \\
\hline
\end{tabular}




\section{Conduct of Operations Applicability Matrix for Light Science \& Industry Facilities}

\begin{tabular}{|c|c|c|c|c|}
\hline $\begin{array}{l}\text { ES\&H MANUAL } \\
\text { DOCUMENT } 3.5 \\
\text { SECTION }\end{array}$ & $\begin{array}{l}\text { REQUISITES FOR SECTION } \\
\text { ELEMENTS }\end{array}$ & $\begin{array}{l}\text { APPLICABLE } \\
\text { YES/NO }\end{array}$ & $\begin{array}{c}\text { RESPONSIBILITY } \\
\text { FOR } \\
\text { COMPLIANCE } \\
\text { FMC/PMC }^{1} \\
\end{array}$ & $\begin{array}{l}\text { COMMENTS AND/OR REFERENCE FOR } \\
\text { VERIFICATION OF COMPLIANCE }\end{array}$ \\
\hline $\begin{array}{l}\text { 5.2.6. Suspension of } \\
\text { Training }\end{array}$ & $\begin{array}{l}\text { Ensure trainees understand their role } \\
\text { during abnormal conditions. }\end{array}$ & Yes & FMC/PMC & $\begin{array}{l}\text { CMELS- } 330 \text { requires the RI to ensure that trainees } \\
\text { only work with experienced personnel according to } \\
\text { existing procedures, and that they are aware of } \\
\text { operating limits and hazards. CMELS- } 330 \text { requires } \\
\text { the host and RI to ensure visitors, guests, students, } \\
\text { and vendors either have the required training or are } \\
\text { escorted. }\end{array}$ \\
\hline $\begin{array}{l}\text { 5.2.7. Maximum } \\
\text { Number of Trainees }\end{array}$ & $\begin{array}{l}\text { Establish limits for the number of OJT } \\
\text { trainees. }\end{array}$ & No & NA & $\begin{array}{l}\text { CMELS does not limit the number of OJT trainees. } \\
\text { OJT requirements are identified in Document } 40.1 \text {, } \\
\text { "LLNL Training Program Manual," and CMELS- } 330 \\
\text { requires the RI to ensure required training, including } \\
\text { on-the-job training (OJT) for all trainees, is } \\
\text { completed and to ensure workers have necessary } \\
\text { qualifications. }\end{array}$ \\
\hline \multicolumn{5}{|l|}{$\begin{array}{c}\text { INVESTIGATION OF } \\
\text { ABNORMAL } \\
\text { EVENTS } \\
\text { SECTION } 6.0 \\
\end{array}$} \\
\hline $\begin{array}{l}\text { 6.2.1. Events } \\
\text { Requiring } \\
\text { Investigation }\end{array}$ & $\begin{array}{l}\text { Identify types of events that require } \\
\text { investigation }\end{array}$ & Yes & FMC/PMC & $\begin{array}{l}\text { LLNL ES\&H Manual, Document } 4.3 \text {, (LLNL } \\
\text { Implementation Procedure for Reporting } \\
\text { Occurrences to the Department of Energy (DOE) } \\
\text { Order } 231.1 \mathrm{~A} \text {, "Environment, Safety and Health } \\
\text { Reporting," and DOE Manual 231.1-2, "Occurrence } \\
\text { Reporting and Processing of Operations } \\
\text { Information." }\end{array}$ \\
\hline
\end{tabular}




\section{Conduct of Operations Applicability Matrix for Light Science \& Industry Facilities}

\begin{tabular}{|c|c|c|c|c|}
\hline $\begin{array}{l}\text { ES\&H MANUAL } \\
\text { DOCUMENT } 3.5 \\
\text { SECTION }\end{array}$ & $\begin{array}{l}\text { REQUISITES FOR SECTION } \\
\text { ELEMENTS }\end{array}$ & $\begin{array}{c}\text { APPLICABLE } \\
\text { YES/NO }\end{array}$ & $\begin{array}{c}\text { RESPONSIBILITY } \\
\text { FOR } \\
\text { COMPLIANCE } \\
\text { FMC/PMC }^{1} \\
\end{array}$ & $\begin{array}{l}\text { COMMENTS AND/OR REFERENCE FOR } \\
\text { VERIFICATION OF COMPLIANCE }\end{array}$ \\
\hline $\begin{array}{l}\text { 6.2.2. Investigation } \\
\text { Responsibility }\end{array}$ & $\begin{array}{l}\text { Identify Event Investigation } \\
\text { responsibilities }\end{array}$ & Yes & FMC/PMC & $\begin{array}{l}\text { CMELS-330 requires that the AD utilize the } \\
\text { Assurance Manager to ensure that incident } \\
\text { response, analysis, and recording conform to } \\
\text { requirements of the LLNL ES\&H Manual. } \\
\text { CMS-322 specifies processes for investigation of } \\
\text { abnormal events in accordance with the LLNL } \\
\text { ES\&H Manual, Document } 4.3 \text {, (LLNL } \\
\text { Implementation Procedure for Reporting } \\
\text { Occurrences to the Department of Energy (DOE) } \\
\text { Order } 231.1 \mathrm{~A} \text {, "Environment, Safety and Health } \\
\text { Reporting," and DOE Manual } 231.1-2 \text {, "Occurrence } \\
\text { Reporting and Processing of Operations } \\
\text { Information." }\end{array}$ \\
\hline $\begin{array}{l}\text { 6.2.3. Investigator } \\
\text { Qualification }\end{array}$ & $\begin{array}{l}\text { Investigators complete training } \\
\text { requirements }\end{array}$ & Yes & FMC/PMC & $\begin{array}{l}\text { ES\&H Manual Document } 4.6 \text { specifies training } \\
\text { requirements }\end{array}$ \\
\hline $\begin{array}{l}\text { 6.2.4. Information to } \\
\text { be Gathered }\end{array}$ & Collect required information & Yes & $\mathrm{FMC} / \mathrm{PMC}$ & $\begin{array}{l}\text { ES\&H Manual Document } 4.6 \text { specifies investigation } \\
\text { procedures. }\end{array}$ \\
\hline $\begin{array}{l}\text { 6.2.5. Event } \\
\text { Investigation }\end{array}$ & Conduct structured review of events & Yes & FMC/PMC & $\begin{array}{l}\text { CMELS-330 requires that the AD utilize the } \\
\text { Assurance Manager to ensure that incident } \\
\text { response, analysis, and recording conform to } \\
\text { requirements of the LLNL ES\&H Manual. } \\
\text { CMELS-330 specifies processes for investigation of } \\
\text { abnormal events in accordance with the LLNL } \\
\text { ES\&H Manual, Document } 4.3 \text {, (LLNL } \\
\text { Implementation Procedure for Reporting } \\
\text { Occurrences to the Department of Energy (DOE) } \\
\text { Order } 231.1 \mathrm{~A} \text {, "Environment, Safety and Health } \\
\text { Reporting," and DOE Manual 231.1-2, "Occurrence } \\
\text { Reporting and Processing of Operations } \\
\text { Information." }\end{array}$ \\
\hline
\end{tabular}




\section{Conduct of Operations Applicability Matrix for Light Science \& Industry Facilities}

\begin{tabular}{|c|c|c|c|c|}
\hline $\begin{array}{l}\text { ES\&H MANUAL } \\
\text { DOCUMENT } 3.5 \\
\text { SECTION }\end{array}$ & $\begin{array}{l}\text { REQUISITES FOR SECTION } \\
\text { ELEMENTS }\end{array}$ & $\begin{array}{l}\text { APPLICABLE } \\
\text { YES/NO }\end{array}$ & $\begin{array}{l}\text { RESPONSIBILITY } \\
\text { FOR } \\
\text { COMPLIANCE } \\
\text { FMC/PMC }^{1}\end{array}$ & $\begin{array}{l}\text { COMMENTS AND/OR REFERENCE FOR } \\
\text { VERIFICATION OF COMPLIANCE }\end{array}$ \\
\hline $\begin{array}{l}\text { 6.2.6. Investigative } \\
\text { Report }\end{array}$ & Prepare investigative reports & Yes & FMC/PMC & $\begin{array}{l}\text { CMELS-330 requires that the AD utilize the } \\
\text { Assurance Manager to ensure that incident } \\
\text { response, analysis, and recording conform to } \\
\text { requirements of the LLNL ES\&H Manual. } \\
\text { CMELS-330 specifies processes for investigation of } \\
\text { abnormal events in accordance with the LLNL } \\
\text { ES\&H Manual, Document } 4.3 \text {, (LLNL } \\
\text { Implementation Procedure for Reporting } \\
\text { Occurrences to the Department of Energy (DOE) } \\
\text { Order } 231.1 \mathrm{~A} \text {, "Environment, Safety and Health } \\
\text { Reporting," and DOE Manual 231.1-2, "Occurrence } \\
\text { Reporting and Processing of Operations } \\
\text { Information." }\end{array}$ \\
\hline 6.2.7. Event Training & $\begin{array}{l}\text { Evaluate events for training benefit } \\
\text { and conduct the appropriate training }\end{array}$ & Yes & FMC/PMC & $\begin{array}{l}\text { Need for training is considered as part of the } \\
\text { process described in ES\&H Manual Document 4.6. }\end{array}$ \\
\hline \multirow[t]{2}{*}{ 6.2.8. Event Trending } & $\begin{array}{l}\text { Patterns of deficiencies should be } \\
\text { trended and a report (causes and } \\
\text { trends) provided to the management } \\
\text { chain. }\end{array}$ & Yes & PMC & $\begin{array}{l}\text { CMELS-330 defines provisions for } \\
\text { reviewing/analyzing safety data within the } \\
\text { Directorate. CMLS- } 305 \text { defines provisions for rolling } \\
\text { up data to the Institutional level for trending. } \\
\text { Trend analysis requirements are included in } \\
\text { CMELS-305, "ES\&H Self-Assessment Plan." }\end{array}$ \\
\hline & $\begin{array}{l}\text { Information in the event trending } \\
\text { report should be communicated to } \\
\text { appropriate facility personnel }\end{array}$ & Yes & PMC & $\begin{array}{l}\text { Reports are provided to FMs per ES\&H Manual } \\
\text { Document } 4.1 .\end{array}$ \\
\hline 6.2.9. Sabotage & $\begin{array}{l}\text { Response and investigative } \\
\text { procedures for suspected sabotage } \\
\text { should include the guidance in } \\
\text { Section 6.2.9. }\end{array}$ & Yes & FMC/PMC & $\begin{array}{l}\text { ES\&H Manual Documents } 4.5,4.6 \text { and } 4.7 \\
\text { (Incidents - Notification, Analysis, and Reporting; } \\
\text { Incident Analysis Manual; and ES\&H Analysis } \\
\text { Methods) will be followed. CMELS-330 specifies } \\
\text { processes for investigation of abnormal events. } \\
\text { ES\&H Manual, Document 22.1, Emergency } \\
\text { Preparedness and Response; } 4.6 \text {, Incident Analysis } \\
\text { Manual. }\end{array}$ \\
\hline
\end{tabular}




\section{Conduct of Operations Applicability Matrix for Light Science \& Industry Facilities}

\begin{tabular}{|c|c|c|c|c|}
\hline $\begin{array}{l}\text { ES\&H MANUAL } \\
\text { DOCUMENT } 3.5 \\
\text { SECTION }\end{array}$ & $\begin{array}{c}\text { REQUISITES FOR SECTION } \\
\text { ELEMENTS }\end{array}$ & $\begin{array}{l}\text { APPLICABLE } \\
\text { YES/NO }\end{array}$ & $\begin{array}{l}\text { RESPONSIBILITY } \\
\text { FOR } \\
\text { COMPLIANCE } \\
\text { FMC/PMC }^{1}\end{array}$ & $\begin{array}{l}\text { COMMENTS AND/OR REFERENCE FOR } \\
\text { VERIFICATION OF COMPLIANCE }\end{array}$ \\
\hline \multicolumn{5}{|l|}{$\begin{array}{l}\text { NOTIFICATIONS } \\
\text { SECTION } 7.0\end{array}$} \\
\hline $\begin{array}{l}\text { 7.2.1. Notification } \\
\text { Procedures }\end{array}$ & Establish notification procedures. & Yes & FMC/PMC & $\begin{array}{l}\text { All personnel working in CMELS facilities and } \\
\text { personnel working on CMELS activities in non- } \\
\text { CMELS facilities and at offsite locations are } \\
\text { responsible to notify the Facility Point of Contact } \\
\text { (FPOC) and their division management of any } \\
\text { unplanned events or unexpected conditions that } \\
\text { could potentially be reportable (per CMELS-330). } \\
\text { ES\&H Manual, Document 4.3, LLNL Implementation } \\
\text { Procedure for Reporting Occurrences to DOE. }\end{array}$ \\
\hline $\begin{array}{l}\text { 7.2.2.Notification } \\
\text { Responsibility }\end{array}$ & $\begin{array}{l}\text { Identify the individual (facility } \\
\text { management or program } \\
\text { management) responsible for initiating } \\
\text { the notification process. }\end{array}$ & Yes & FMC/PMC & $\begin{array}{l}\text { CMLS-409 (Site } 200 \text { Employee Emergency } \\
\text { Response Self-Help Guide), and CMELS-330 } \\
\text { identify notification procedure and reporting chains. } \\
\text { All CMELS operations managers (e.g. FMs, } \\
\text { DDL/Ops, DAD/Ops, Als, etc.) are required to } \\
\text { complete EM2010. Training completions are } \\
\text { documented in LTRAIN. } \\
\text { ES\&H Manual, Document 4.3, LLNL Implementation } \\
\text { Procedure for Reporting Occurrences to DOE. }\end{array}$ \\
\hline $\begin{array}{l}\text { 7.2.3. Names and } \\
\text { Phone Numbers }\end{array}$ & $\begin{array}{l}\text { Contact information for occurrence } \\
\text { reporting is made available. }\end{array}$ & Yes & FMC/PMC & $\begin{array}{l}\text { CMLS-409, and CMELS-330 identify notification } \\
\text { procedure and reporting chains, which includes } \\
\text { notification of the Assurance Manager. } \\
\text { LLNL Emergency Contact Roster. }\end{array}$ \\
\hline
\end{tabular}




\section{Conduct of Operations Applicability Matrix for Light Science \& Industry Facilities}

\begin{tabular}{|c|c|c|c|c|}
\hline $\begin{array}{l}\text { ES\&H MANUAL } \\
\text { DOCUMENT } 3.5 \\
\text { SECTION }\end{array}$ & $\begin{array}{l}\text { REQUISITES FOR SECTION } \\
\text { ELEMENTS }\end{array}$ & $\begin{array}{l}\text { APPLICABLE } \\
\text { YES/NO }\end{array}$ & $\begin{array}{l}\text { RESPONSIBILITY } \\
\text { FOR } \\
\text { COMPLIANCE } \\
\text { FMC/PMC }^{1}\end{array}$ & $\begin{array}{l}\text { COMMENTS AND/OR REFERENCE FOR } \\
\text { VERIFICATION OF COMPLIANCE }\end{array}$ \\
\hline 7.2.4. Documentation & $\begin{array}{l}\text { Maintain a formal record of } \\
\text { notifications. }\end{array}$ & Yes & FMC/PMC & $\begin{array}{l}\text { CMLS-409 (Site } 200 \text { Employee Emergency } \\
\text { Response Self-Help Guide), and CMELS-330 } \\
\text { identify notification procedure and reporting chains. } \\
\text { All CMELS operations managers (e.g. FMs, } \\
\text { DDL/Ops, DAD/Ops, Als, etc.) are required to } \\
\text { complete EM2010. Training completions are } \\
\text { documented in LTRAIN. } \\
\text { ES\&H Manual, Document 4.3, LLNL Implementation } \\
\text { Procedure for Reporting Occurrences to DOE. } \\
\text { Formal records of ORPS notifications are } \\
\text { maintained by the Institutional Occurrence } \\
\text { Reporting Manager. }\end{array}$ \\
\hline $\begin{array}{l}\text { 7.2.5. Communication } \\
\text { Equipment }\end{array}$ & $\begin{array}{l}\text { Maintain communication equipment } \\
\text { adequate for notification procedure. }\end{array}$ & Yes & FMC/PMC & $\begin{array}{l}\text { Communication equipment is maintained by the } \\
\text { Institution. }\end{array}$ \\
\hline $\begin{array}{l}\text { CONTROL OF } \\
\text { EQUIPMENT AND } \\
\text { SYSTEMS STATUS } \\
\text { SECTION } 8.0 \\
\end{array}$ & & & & \\
\hline \multirow[t]{3}{*}{$\begin{array}{l}\text { 8.2.1. Status Change } \\
\text { Authorization and } \\
\text { Reporting }\end{array}$} & $\begin{array}{l}\text { Identify equipment and/or systems } \\
\text { whose configuration must be } \\
\text { maintained. }\end{array}$ & No & NA & $\begin{array}{l}\text { There are no configuration items identified for these } \\
\text { facilities. }\end{array}$ \\
\hline & $\begin{array}{l}\text { Establish a formal mechanism to } \\
\text { authorize changes in configuration or } \\
\text { status. }\end{array}$ & No & NA & $\begin{array}{l}\text { There are no configuration items identified for these } \\
\text { facilities. }\end{array}$ \\
\hline & $\begin{array}{l}\text { Establish a formal mechanism to } \\
\text { ensure personnel are kept informed of } \\
\text { any changes in the operational status } \\
\text { of the equipment or systems. }\end{array}$ & No & NA & $\begin{array}{l}\text { There are no configuration items identified for these } \\
\text { facilities. }\end{array}$ \\
\hline $\begin{array}{l}\text { 8.2.2. Equipment and } \\
\text { System Alignment }\end{array}$ & $\begin{array}{l}\text { Equipment and systems are aligned } \\
\text { or checked for proper alignment } \\
\text { before operation. }\end{array}$ & No & NA & $\begin{array}{l}\text { There are no configuration items identified for these } \\
\text { facilities. }\end{array}$ \\
\hline
\end{tabular}




\section{Conduct of Operations Applicability Matrix for Light Science \& Industry Facilities}

\begin{tabular}{|c|c|c|c|c|}
\hline $\begin{array}{l}\text { ES\&H MANUAL } \\
\text { DOCUMENT } 3.5 \\
\text { SECTION }\end{array}$ & $\begin{array}{c}\text { REQUISITES FOR SECTION } \\
\text { ELEMENTS }\end{array}$ & $\begin{array}{l}\text { APPLICABLE } \\
\text { YES/NO }\end{array}$ & $\begin{array}{l}\text { RESPONSIBILITY } \\
\text { FOR } \\
\text { COMPLIANCE } \\
\text { FMC/PMC }^{1}\end{array}$ & $\begin{array}{l}\text { COMMENTS AND/OR REFERENCE FOR } \\
\text { VERIFICATION OF COMPLIANCE }\end{array}$ \\
\hline $\begin{array}{l}\text { 8.2.3. Equipment } \\
\text { Locking and Tagging }\end{array}$ & $\begin{array}{l}\text { Lockout and tagout procedures are in } \\
\text { place. }\end{array}$ & Yes & FMC/PMC & $\begin{array}{l}\text { Lockout and tagout is implemented through the IWS } \\
\text { process in accordance with Document } 12.6 \text { of the } \\
\text { LLNL ES\&H Manual. CMELS Facility Operations } \\
\text { personnel do not perform lockout \& tagout. }\end{array}$ \\
\hline $\begin{array}{l}\text { 8.2.4. Operational } \\
\text { Limits Compliance }\end{array}$ & $\begin{array}{l}\text { Establish administrative controls that } \\
\text { document compliance with operating } \\
\text { limits. }\end{array}$ & Yes & FMC/PMC & $\begin{array}{l}\text { Facility concurrence on work to be conducted as } \\
\text { documented in an IWS, as described in CMELS- } 330 \\
\text { and ES\&H Manual Document } 2.1 \text {, is provided to } \\
\text { ensure the activity is within the safety basis } \\
\text { envelope of a facility. } \\
\text { Authorizing Individuals monitor the work to ensure } \\
\text { that hazards are identified, controls are developed } \\
\text { and implemented, and that ES\&H requirements are } \\
\text { met. Where required, equipment run logs document } \\
\text { that operating limits are observed, that critical } \\
\text { measurement and test equipment is operational, } \\
\text { and that routine maintenance and calibrations are } \\
\text { conducted. }\end{array}$ \\
\hline $\begin{array}{l}\text { 8.2.5. Equipment } \\
\text { Deficiency } \\
\text { Identification and } \\
\text { Documentation }\end{array}$ & $\begin{array}{l}\text { Establish method for identifying, } \\
\text { reporting, and documenting } \\
\text { equipment deficiencies. }\end{array}$ & Yes & FMC/PMC & $\begin{array}{l}\text { CMLS-305, CMS-306 (Deficiency Tracking } \\
\text { Management Plan) and CMELS-330 define } \\
\text { processes to regularly self assess operations, } \\
\text { facilities, activities and to report deficiencies. Other } \\
\text { feedback and improvement techniques are defined } \\
\text { in CMELS-330. Scheduled inspections/self- } \\
\text { assessments are used in addition to employee } \\
\text { reports and may initiate ITS deficiencies. Suspect } \\
\text { Counterfeit Inspections are performed every three } \\
\text { years. } \\
\text { ES\&H Manual, Document 4.2, "ES\&H Issues and } \\
\text { Deficiencies Management." }\end{array}$ \\
\hline
\end{tabular}




\section{Conduct of Operations Applicability Matrix for Light Science \& Industry Facilities}

\begin{tabular}{|c|c|c|c|c|}
\hline $\begin{array}{l}\text { ES\&H MANUAL } \\
\text { DOCUMENT } 3.5 \\
\text { SECTION }\end{array}$ & $\begin{array}{l}\text { REQUISITES FOR SECTION } \\
\text { ELEMENTS }\end{array}$ & $\begin{array}{l}\text { APPLICABLE } \\
\text { YES/NO }\end{array}$ & $\begin{array}{l}\text { RESPONSIBILITY } \\
\text { FOR } \\
\text { COMPLIANCE } \\
\text { FMC/PMC }^{1} \\
\end{array}$ & $\begin{array}{l}\text { COMMENTS AND/OR REFERENCE FOR } \\
\text { VERIFICATION OF COMPLIANCE }\end{array}$ \\
\hline $\begin{array}{l}\text { 8.2.6. Work } \\
\text { Authorization and } \\
\text { Documentation }\end{array}$ & $\begin{array}{l}\text { Written authorization should be } \\
\text { obtained for all shift activities } \\
\text { (including modifications or } \\
\text { maintenance) on equipment or } \\
\text { systems important to safety, that } \\
\text { affects operations, or that changes } \\
\text { control indications or alarms. }\end{array}$ & Yes & FMC/PMC & $\begin{array}{l}\text { ES\&H Manual, Document 2.1, "General Worker } \\
\text { Responsibilities and Integrated Safety } \\
\text { Management," and Document 2.2, "Managing ES\&H } \\
\text { for LLNL Work." }\end{array}$ \\
\hline $\begin{array}{l}\text { 8.2.7. Equipment } \\
\text { Post-Maintenance } \\
\text { Testing and Return to } \\
\text { Service }\end{array}$ & $\begin{array}{l}\text { Establish post- } \\
\text { modification/maintenance testing } \\
\text { procedures for equipment or systems } \\
\text { important to safety. }\end{array}$ & Yes & FMC/PMC & $\begin{array}{l}\text { Safety Basis Documents do not identify any SSCs } \\
\text { requiring post-maintenance testing. SSC's important } \\
\text { to worker safety and their associated post- } \\
\text { modification/maintenance testing procedures are } \\
\text { identified in IWSs. Requirements for post } \\
\text { modification/maintenance testing for fume hoods, } \\
\text { glove boxes, and BSCs are identified in ES\&H } \\
\text { Manual Document } 12.4 \text { "Work Enclosures and Local } \\
\text { Exhaust Systems for Toxic and Radioactive } \\
\text { Materials." }\end{array}$ \\
\hline 8.2.8. Alarm Status & $\begin{array}{l}\text { Ensure there is a clear } \\
\text { indication/understanding of alarm } \\
\text { status. }\end{array}$ & Yes & FMC/PMC & $\begin{array}{l}\text { Alarms important to worker safety as identified in } \\
\text { IWSs are provided with appropriate signage to } \\
\text { indicate meaning and status of alarm. Alarms } \\
\text { whose indications are not required for worker, public } \\
\text { or environmental safety are properly labeled. }\end{array}$ \\
\hline $\begin{array}{l}\text { 8.2.9. Temporary } \\
\text { Modification Control }\end{array}$ & $\begin{array}{l}\text { Establish control for installing } \\
\text { temporary modifications to SSCs } \\
\text { under configuration management. }\end{array}$ & No & NA & $\begin{array}{l}\text { There are no configuration items identified for these } \\
\text { facilities. }\end{array}$ \\
\hline $\begin{array}{l}\text { 8.2.10. Distribution } \\
\text { and Control of } \\
\text { Equipment and } \\
\text { System Document }\end{array}$ & $\begin{array}{l}\text { Establish system for document control } \\
\text { and distribution for equipment or } \\
\text { systems under configuration } \\
\text { management. }\end{array}$ & No & NA & $\begin{array}{l}\text { There are no configuration items identified for these } \\
\text { facilities. }\end{array}$ \\
\hline
\end{tabular}




\section{Conduct of Operations Applicability Matrix for Light Science \& Industry Facilities}

\begin{tabular}{|c|c|c|c|c|}
\hline $\begin{array}{l}\text { ES\&H MANUAL } \\
\text { DOCUMENT } 3.5 \\
\text { SECTION }\end{array}$ & $\begin{array}{c}\text { REQUISITES FOR SECTION } \\
\text { ELEMENTS }\end{array}$ & $\begin{array}{l}\text { APPLICABLE } \\
\text { YES/NO }\end{array}$ & $\begin{array}{l}\text { RESPONSIBILITY } \\
\text { FOR } \\
\text { COMPLIANCE } \\
\text { FMC/PMC }^{1}\end{array}$ & $\begin{array}{l}\text { COMMENTS AND/OR REFERENCE FOR } \\
\text { VERIFICATION OF COMPLIANCE }\end{array}$ \\
\hline \multicolumn{5}{|l|}{$\begin{array}{l}\text { LOCKOUTS AND } \\
\text { TAGOUTS } \\
\text { SECTION } 9.0\end{array}$} \\
\hline $\begin{array}{l}\text { 9.2.1. Lockout/Tagout } \\
\text { Use }\end{array}$ & $\begin{array}{l}\text { Work supervisors of LLNL and } \\
\text { subcontract workers shall satisfy } \\
\text { LLNL's lockout and tag program } \\
\text { requirements described in Document } \\
12.6 \text {. }\end{array}$ & Yes & FMC/PMC & $\begin{array}{l}\text { Lockout and tagout is implemented through the IWS } \\
\text { process in accordance with Document } 12.6 \text { of the } \\
\text { LLNL ES\&H Manual. }\end{array}$ \\
\hline \multirow[t]{2}{*}{$\begin{array}{l}\text { 9.2.2. Lockout and } \\
\text { Tagout } \\
\text { Implementation }\end{array}$} & $\begin{array}{l}\text { Lockout/Tagout implementation shall } \\
\text { be in accordance with Document } \\
12.6 .\end{array}$ & Yes & FMC/PMC & $\begin{array}{l}\text { Lockout and tagout is implemented through the IWS } \\
\text { process in accordance with Document } 12.6 \text { of the } \\
\text { LLNL ES\&H Manual. }\end{array}$ \\
\hline & $\begin{array}{l}\text { When appropriate, lockout and tag } \\
\text { requirements are incorporated into (or } \\
\text { referenced in) FSPs, IWS/SPs, or } \\
\text { SOPs. }\end{array}$ & Yes & FMC/PMC & $\begin{array}{l}\text { ES\&H Manual, Document 12.6, LLNL } \\
\text { Lockout/Tagout Program. }\end{array}$ \\
\hline $\begin{array}{l}\text { 9.2.3. Protective } \\
\text { Materials and } \\
\text { Hardware }\end{array}$ & $\begin{array}{l}\text { Adequate protective materials and } \\
\text { hardware for lockout and tagout are } \\
\text { provided. }\end{array}$ & Yes & $\mathrm{FMC/PMC}$ & $\begin{array}{l}\text { ES\&H Manual, Document 12.6, LLNL } \\
\text { Lockout/Tagout Program. }\end{array}$ \\
\hline $\begin{array}{l}\text { 9.2.4. Lockout/Tagout } \\
\text { Program }\end{array}$ & $\begin{array}{l}\text { A lockout/tagout program has been } \\
\text { established. }\end{array}$ & Yes & FMC/PMC & $\begin{array}{l}\text { Lockout and tagout is implemented through the IWS } \\
\text { process in accordance with Document } 12.6 \text { of the } \\
\text { LLNL ES\&H Manual. }\end{array}$ \\
\hline $\begin{array}{l}\text { 9.2.5. Procedures for } \\
\text { Lockout/Tagout }\end{array}$ & $\begin{array}{l}\text { Lockout/tagout procedures are } \\
\text { developed, documented, validated, } \\
\text { and utilized. }\end{array}$ & Yes & FMC/PMC & $\begin{array}{l}\text { ES\&H Manual, Document 12.6, LLNL } \\
\text { Lockout/Tagout Program. }\end{array}$ \\
\hline $\begin{array}{l}\text { 9.2.6. Application of } \\
\text { Lockout/Tagout }\end{array}$ & $\begin{array}{l}\text { Established lockout/tagout procedures } \\
\text { cover the elements and actions } \\
\text { described in Section } 9.2 .6 \text { and } \\
\text { Document } 12.6 \text {. }\end{array}$ & Yes & FMC/PMC & $\begin{array}{l}\text { ES\&H Manual, Document 12.6, LLNL } \\
\text { Lockout/Tagout Program. }\end{array}$ \\
\hline
\end{tabular}




\section{Conduct of Operations Applicability Matrix for Light Science \& Industry Facilities}

\begin{tabular}{|c|c|c|c|c|}
\hline $\begin{array}{l}\text { ES\&H MANUAL } \\
\text { DOCUMENT } 3.5 \\
\text { SECTION }\end{array}$ & $\begin{array}{c}\text { REQUISITES FOR SECTION } \\
\text { ELEMENTS }\end{array}$ & $\begin{array}{l}\text { APPLICABLE } \\
\text { YES/NO }\end{array}$ & $\begin{array}{c}\text { RESPONSIBILITY } \\
\text { FOR } \\
\text { COMPLIANCE } \\
\text { FMC/PMC }^{1}\end{array}$ & $\begin{array}{l}\text { COMMENTS AND/OR REFERENCE FOR } \\
\text { VERIFICATION OF COMPLIANCE }\end{array}$ \\
\hline $\begin{array}{l}\text { 9.2.7. Testing or } \\
\text { Positioning of } \\
\text { Equipment or } \\
\text { Components }\end{array}$ & $\begin{array}{l}\text { For temporary removal of } \\
\text { Lockout/Tagout devices, follow the } \\
\text { actions described in Section 9.2.7. }\end{array}$ & Yes & FMC/PMC & $\begin{array}{l}\text { ES\&H Manual, Document 12.6, LLNL } \\
\text { Lockout/Tagout Program. }\end{array}$ \\
\hline $\begin{array}{l}\text { 9.2.8. Periodic } \\
\text { Inspections }\end{array}$ & $\begin{array}{l}\text { Conduct periodic inspections to } \\
\text { determine adequacy of lockout/tagout } \\
\text { program, as described in Document } \\
12.6 \text {. }\end{array}$ & Yes & FMC/PMC & $\begin{array}{l}\text { Lockout and tagout is implemented through the IWS } \\
\text { process in accordance with Document } 12.6 \text { of the } \\
\text { LLNL ES\&H Manual. }\end{array}$ \\
\hline 9.2.9. Caution Tags & $\begin{array}{l}\text { Use of caution tags should follow } \\
\text { protocol described in Section 9.2.9 } \\
\text { and as described in Document 12.6. }\end{array}$ & Yes & FMC/PMC & $\begin{array}{l}\text { ES\&H Manual, Document 12.6, LLNL } \\
\text { Lockout/Tagout Program. }\end{array}$ \\
\hline $\begin{array}{l}\text { 9.2.10. Training and } \\
\text { Communication }\end{array}$ & $\begin{array}{l}\text { Personnel shall have training } \\
\text { consistent with Section 9.2.10. }\end{array}$ & Yes & FMC/PMC & $\begin{array}{l}\text { ES\&H Manual, Document 12.6, LLNL } \\
\text { Lockout/Tagout Program. }\end{array}$ \\
\hline $\begin{array}{l}\text { 9.2.11. Lockout or } \\
\text { Tagout } \\
\text { Implementation }\end{array}$ & $\begin{array}{l}\text { Only authorized, qualified personnel } \\
\text { accomplish lockout/tagout, as } \\
\text { described in Document } 12.6 \text {. }\end{array}$ & Yes & FMC/PMC & $\begin{array}{l}\text { ES\&H Manual, Document 12.6, LLNL } \\
\text { Lockout/Tagout Program. }\end{array}$ \\
\hline $\begin{array}{l}\text { 9.2.12. Notification of } \\
\text { Personnel }\end{array}$ & $\begin{array}{l}\text { Personnel affected by the } \\
\text { lockout/tagout application or removal } \\
\text { are notified, as described in } \\
\text { Document } 12.6 \text {. }\end{array}$ & Yes & FMC/PMC & $\begin{array}{l}\text { ES\&H Manual, Document 12.6, LLNL } \\
\text { Lockout/Tagout Program. }\end{array}$ \\
\hline $\begin{array}{l}\text { 9.2.13. Outside } \\
\text { Contractors }\end{array}$ & $\begin{array}{l}\text { Outside contractors adhere to } \\
\text { lockout/tagout procedures as } \\
\text { described in Document } 12.6 \text {. }\end{array}$ & Yes & FMC/PMC & $\begin{array}{l}\text { ES\&H Manual, Document 12.6, LLNL } \\
\text { Lockout/Tagout Program. }\end{array}$ \\
\hline $\begin{array}{l}\text { 9.2.14. Group } \\
\text { Lockouts or Tagouts }\end{array}$ & $\begin{array}{l}\text { Adhere to group lockout/tagouts } \\
\text { procedures as described in Document } \\
12.6 \text {. }\end{array}$ & Yes & FMC/PMC & $\begin{array}{l}\text { ES\&H Manual, Document 12.6, LLNL } \\
\text { Lockout/Tagout Program. }\end{array}$ \\
\hline
\end{tabular}




\section{Conduct of Operations Applicability Matrix for Light Science \& Industry Facilities}

\begin{tabular}{|c|c|c|c|c|}
\hline $\begin{array}{l}\text { ES\&H MANUAL } \\
\text { DOCUMENT } 3.5 \\
\text { SECTION }\end{array}$ & $\begin{array}{c}\text { REQUISITES FOR SECTION } \\
\text { ELEMENTS }\end{array}$ & $\begin{array}{l}\text { APPLICABLE } \\
\text { YES/NO }\end{array}$ & $\begin{array}{l}\text { RESPONSIBILITY } \\
\text { FOR } \\
\text { COMPLIANCE } \\
\text { FMC/PMC }^{1} \\
\end{array}$ & $\begin{array}{l}\text { COMMENTS AND/OR REFERENCE FOR } \\
\text { VERIFICATION OF COMPLIANCE }\end{array}$ \\
\hline $\begin{array}{l}\text { 9.2.15. Shift or } \\
\text { Personnel Changes }\end{array}$ & $\begin{array}{l}\text { Adhere to procedures for transferring } \\
\text { locks and tags when personnel or } \\
\text { shifts change, as described in } \\
\text { Document } 12.6 \text {. }\end{array}$ & Yes & FMC/PMC & $\begin{array}{l}\text { ES\&H Manual, Document 12.6, LLNL } \\
\text { Lockout/Tagout Program. }\end{array}$ \\
\hline \multicolumn{5}{|l|}{$\begin{array}{l}\text { INDEPENDENT } \\
\text { VERIFICATION } \\
\text { SECTION } 10.0 \\
\end{array}$} \\
\hline $\begin{array}{l}\text { 10.2.1. Components } \\
\text { Requiring } \\
\text { Independent } \\
\text { Verification }\end{array}$ & $\begin{array}{l}\text { Identify components/systems } \\
\text { requiring independent verification } \\
\text { whose improper positioning could } \\
\text { result in an impact to health, safety, } \\
\text { the environment, or significant impact } \\
\text { to programs. }\end{array}$ & No & NA & $\begin{array}{l}\text { No components have been identified in Safety Basis } \\
\text { documentation for CMELS S } 200 \text { LSI facilities or } \\
\text { IWS's that are critical to ensure safe and reliable } \\
\text { operation. }\end{array}$ \\
\hline $\begin{array}{l}\text { 10.2.2. Occasions } \\
\text { Requiring } \\
\text { Independent } \\
\text { Verification }\end{array}$ & $\begin{array}{l}\text { Ensure that independent verification is } \\
\text { conducted and documented following } \\
\text { the guidance in Section 10.2.2. }\end{array}$ & No & NA & $\begin{array}{l}\text { No components have been identified in Safety Basis } \\
\text { documentation for CMELS S } 200 \text { LSI facilities or } \\
\text { IWS's that are critical to ensure safe and reliable } \\
\text { operation. }\end{array}$ \\
\hline $\begin{array}{l}\text { 10.2.3. Verification } \\
\text { Techniques }\end{array}$ & $\begin{array}{l}\text { Ensure that verification techniques } \\
\text { are followed using the guidance in } \\
\text { Section } 10.2 .3 \text {. }\end{array}$ & No & NA & $\begin{array}{l}\text { No components have been identified in Safety Basis } \\
\text { documentation for CMELS S } 200 \text { LSI facilities or } \\
\text { IWS's that are critical to ensure safe and reliable } \\
\text { operation. }\end{array}$ \\
\hline \multicolumn{5}{|l|}{$\begin{array}{l}\text { LOGKEEPING } \\
\text { SECTION } 11.0\end{array}$} \\
\hline $\begin{array}{l}\text { 11.2.1. Establishment } \\
\text { of Operating Logs }\end{array}$ & $\begin{array}{l}\text { Identify operations, areas, or } \\
\text { equipment where formal record- } \\
\text { keeping is required, and assign } \\
\text { logbook-keeping responsibilities. }\end{array}$ & Yes & FMC/PMC & $\begin{array}{l}\text { Some programs require logbooks as part of their QA } \\
\text { program. These logbooks are managed per the } \\
\text { requirements in the respective ALQAP. Logbooks } \\
\text { are required for cranes, facility-related oxygen } \\
\text { deficiency monitors, forklift operations, radiation } \\
\text { area monitors, and emergency eyewash/shower } \\
\text { testing in CMELS Site } 200 \text { facilities. }\end{array}$ \\
\hline
\end{tabular}




\section{Conduct of Operations Applicability Matrix for Light Science \& Industry Facilities}

\begin{tabular}{|c|c|c|c|c|}
\hline $\begin{array}{l}\text { ES\&H MANUAL } \\
\text { DOCUMENT } 3.5 \\
\text { SECTION }\end{array}$ & $\begin{array}{l}\text { REQUISITES FOR SECTION } \\
\text { ELEMENTS }\end{array}$ & $\begin{array}{l}\text { APPLICABLE } \\
\text { YES/NO }\end{array}$ & $\begin{array}{c}\text { RESPONSIBILITY } \\
\text { FOR } \\
\text { COMPLIANCE } \\
\text { FMC/PMC }^{1}\end{array}$ & $\begin{array}{l}\text { COMMENTS AND/OR REFERENCE FOR } \\
\text { VERIFICATION OF COMPLIANCE }\end{array}$ \\
\hline $\begin{array}{l}\text { 11.2.2. Timeliness of } \\
\text { Recordings }\end{array}$ & $\begin{array}{l}\text { Ensure information is added in a } \\
\text { timely manner. }\end{array}$ & Yes & FMC/PMC & $\begin{array}{l}\text { Logbooks are managed per the requirements in the } \\
\text { respective ALQAP. } \\
\text { Logbooks for cranes, oxygen deficiency monitors, } \\
\text { forklifts, and emergency eyewash/showers, } \\
\text { pressing, drying, and radiography operations, and } \\
\text { for quarterly interlock checks will be completed in } \\
\text { accordance with the requirements listed in the } \\
\text { applicable ES\&H Manual sections and CMLS-305. }\end{array}$ \\
\hline $\begin{array}{l}\text { 11.2.3. Information to } \\
\text { be Recorded }\end{array}$ & $\begin{array}{l}\text { Specify the type of information to be } \\
\text { entered in the logbook, using the } \\
\text { guidance in Section 11.2.3. }\end{array}$ & Yes & FMC/PMC & $\begin{array}{l}\text { Logbooks for cranes, oxygen deficiency monitors, } \\
\text { forklifts, and emergency eyewash/showers, } \\
\text { pressing, drying, and radiography operations, and } \\
\text { for quarterly interlock checks will be completed in } \\
\text { accordance with the requirements listed } \mathrm{n} \text { the } \\
\text { applicable ES\&H Manual sections. }\end{array}$ \\
\hline 11.2.4. Legibility & $\begin{array}{l}\text { Logbook entries should be made in a } \\
\text { legible and easily understood manner. }\end{array}$ & Yes & FMC/PMC & $\begin{array}{l}\text { Some programs require logbooks as part of their QA } \\
\text { program. These logbooks are managed per the } \\
\text { requirements in the respective ALQAP. }\end{array}$ \\
\hline 11.2.5. Corrections & $\begin{array}{l}\text { Follow Section } 11.2 .5 \text { for correcting } \\
\text { erroneous entries. }\end{array}$ & Yes & FMC/PMC & $\begin{array}{l}\text { Some programs require logbooks as part of their QA } \\
\text { program. These logbooks are managed per the } \\
\text { requirements in the respective ALQAP. }\end{array}$ \\
\hline 11.2.6. Log Review & $\begin{array}{l}\text { Regularly review the logbook for } \\
\text { conformance with logbook-keeping } \\
\text { requirements. }\end{array}$ & Yes & FMC/PMC & $\begin{array}{l}\text { Work supervisors directly responsible for logbook } \\
\text { entries regarding cranes, oxygen deficiency } \\
\text { monitors, forklifts, eyewashes and showers, } \\
\text { pressing, drying, and radiography operations, and } \\
\text { for quarterly interlock check work areas will regularly } \\
\text { review logbooks in their areas during informal self- } \\
\text { assessments to check for conformance with } \\
\text { logbook-keeping requirements and to spot trends } \\
\text { that may indicate degrading operations so that } \\
\text { corrective action can be taken before an emergency } \\
\text { occurs. }\end{array}$ \\
\hline
\end{tabular}




\section{Conduct of Operations Applicability Matrix for Light Science \& Industry Facilities}

\begin{tabular}{|c|c|c|c|c|}
\hline $\begin{array}{l}\text { ES\&H MANUAL } \\
\text { DOCUMENT } 3.5 \\
\text { SECTION } \\
\end{array}$ & $\begin{array}{l}\text { REQUISITES FOR SECTION } \\
\text { ELEMENTS }\end{array}$ & $\begin{array}{l}\text { APPLICABLE } \\
\text { YES/NO }\end{array}$ & $\begin{array}{l}\text { RESPONSIBILITY } \\
\text { FOR } \\
\text { COMPLIANCE } \\
\text { FMC/PMC }^{1} \\
\end{array}$ & $\begin{array}{l}\text { COMMENTS AND/OR REFERENCE FOR } \\
\text { VERIFICATION OF COMPLIANCE }\end{array}$ \\
\hline $\begin{array}{l}\text { 11.2.7. Care and } \\
\text { Keeping of Logs }\end{array}$ & $\begin{array}{l}\text { Maintain logbooks in a retrievable } \\
\text { manner. }\end{array}$ & Yes & FMC/PMC & $\begin{array}{l}\text { Logbooks for cranes, oxygen deficiency monitors, } \\
\text { forklifts, eyewashes and showers, pressing, drying, } \\
\text { and radiography operations, and for quarterly } \\
\text { interlock checks will be protected from fire, water, or } \\
\text { other types of damage. } \\
\text { Completed logbooks will be retained in a retrievable } \\
\text { manner for time periods specified by the facility } \\
\text { manager or program. }\end{array}$ \\
\hline \multicolumn{5}{|l|}{$\begin{array}{l}\text { OPERATIONS } \\
\text { TURNOVER } \\
\text { SECTION } 12.0 \\
\end{array}$} \\
\hline \multirow[t]{2}{*}{$\begin{array}{l}\text { 12.2.1. Turnover } \\
\text { Checklists }\end{array}$} & $\begin{array}{l}\text { Identify personnel (by position), that } \\
\text { require a shift turnover checklist. }\end{array}$ & No & NA & Shifts are not utilized in CMELS S200 LSI facilities. \\
\hline & Develop shift turnover checklist(s). & No & NA & Shifts are not utilized in CMELS S200 LSI facilities. \\
\hline $\begin{array}{l}\text { 12.2.2. Document } \\
\text { Review }\end{array}$ & $\begin{array}{l}\text { Oncoming operators and supervisors } \\
\text { review documents specified on their } \\
\text { checklists. }\end{array}$ & No & NA & Shifts are not utilized in CMELS S200 LSI facilities. \\
\hline $\begin{array}{l}\text { 12.2.3. Control Panel } \\
\text { Walkdown }\end{array}$ & $\begin{array}{l}\text { Conduct control panel walkdowns as } \\
\text { appropriate. }\end{array}$ & No & NA & Shifts are not utilized in CMELS S200 LSI facilities. \\
\hline $\begin{array}{l}\text { 12.2.4. Discussion } \\
\text { and Exchange of } \\
\text { Responsibility }\end{array}$ & $\begin{array}{l}\text { Conduct discussion and exchange of } \\
\text { responsibility at shift change. }\end{array}$ & No & NA & Shifts are not utilized in CMELS S200 LSI facilities. \\
\hline $\begin{array}{l}\text { 12.2.5. Shift Crew } \\
\text { Briefing }\end{array}$ & $\begin{array}{l}\text { Operations supervisors conduct crew } \\
\text { briefing as required. }\end{array}$ & No & NA & Shifts are not utilized in CMELS S200 LSI facilities. \\
\hline $\begin{array}{l}\text { 12.2.6. Reliefs } \\
\text { Occurring During the } \\
\text { Shift }\end{array}$ & $\begin{array}{l}\text { Specify and document shift turnover } \\
\text { responsibilities. }\end{array}$ & No & NA & Shifts are not utilized in CMELS S200 LSI facilities. \\
\hline
\end{tabular}




\section{Conduct of Operations Applicability Matrix for Light Science \& Industry Facilities}

\begin{tabular}{|c|c|c|c|c|}
\hline $\begin{array}{l}\text { ES\&H MANUAL } \\
\text { DOCUMENT } 3.5 \\
\text { SECTION }\end{array}$ & $\begin{array}{l}\text { REQUISITES FOR SECTION } \\
\text { ELEMENTS }\end{array}$ & $\begin{array}{l}\text { APPLICABLE } \\
\text { YES/NO }\end{array}$ & $\begin{array}{l}\text { RESPONSIBILITY } \\
\text { FOR } \\
\text { COMPLIANCE } \\
\text { FMC/PMC }^{1}\end{array}$ & $\begin{array}{l}\text { COMMENTS AND/OR REFERENCE FOR } \\
\text { VERIFICATION OF COMPLIANCE }\end{array}$ \\
\hline \multicolumn{5}{|l|}{$\begin{array}{c}\text { OPERATIONS } \\
\text { ASPECTS OF } \\
\text { FACILITY } \\
\text { CHEMISTRY AND } \\
\text { UNIQUE } \\
\text { PROCESSES } \\
\text { SECTION } 13.0 \\
\end{array}$} \\
\hline \multirow[t]{2}{*}{$\begin{array}{l}\text { 13.2.1. Operator } \\
\text { Responsibilities }\end{array}$} & $\begin{array}{l}\text { Identify the samples requiring analysis } \\
\text { and analysis to be performed, and } \\
\text { define the range of acceptable results. }\end{array}$ & No & NA & $\begin{array}{l}\text { There are no routine programmatic or facility-related } \\
\text { sampling and analyzing efforts of operating } \\
\text { parameters. Some institutionally required chemical } \\
\text { analysis to protect ES\&H is performed by EPD and } \\
\text { the ES\&H Team. }\end{array}$ \\
\hline & $\begin{array}{l}\text { Ensure that workers involved in } \\
\text { sampling and analyses understand } \\
\text { their responsibilities. }\end{array}$ & No & NA & $\begin{array}{l}\text { There are no routine programmatic or facility-related } \\
\text { sampling and analyzing efforts of operating } \\
\text { parameters. Some institutionally required chemical } \\
\text { analysis to protect ES\&H is performed by EPD and } \\
\text { the ES\&H Team. }\end{array}$ \\
\hline $\begin{array}{l}\text { 13.2.2. Operator } \\
\text { Knowledge }\end{array}$ & $\begin{array}{l}\text { Ensure workers have the necessary } \\
\text { training and equipment to carry out } \\
\text { their specified tasks. }\end{array}$ & No & NA & $\begin{array}{l}\text { There are no routine programmatic or facility-related } \\
\text { sampling and analyzing efforts of operating } \\
\text { parameters. Some institutionally required chemical } \\
\text { analysis to protect ES\&H is performed by EPD and } \\
\text { the ES\&H Team. }\end{array}$ \\
\hline $\begin{array}{l}\text { 13.2.3. Operator } \\
\text { Response to Process } \\
\text { Problems }\end{array}$ & $\begin{array}{l}\text { Respond to out-of-range results or } \\
\text { process parameters. }\end{array}$ & No & NA & $\begin{array}{l}\text { There are no routine programmatic or facility-related } \\
\text { sampling and analyzing efforts of operating } \\
\text { parameters. Some institutionally required chemical } \\
\text { analysis to protect ES\&H is performed by EPD and } \\
\text { the ES\&H Team. }\end{array}$ \\
\hline $\begin{array}{l}\text { 13.2.4. } \\
\text { Communication } \\
\text { Between Operations } \\
\text { and Process } \\
\text { Personnel }\end{array}$ & $\begin{array}{l}\text { Maintain communication between } \\
\text { operations and process personnel. }\end{array}$ & No & NA & $\begin{array}{l}\text { There are no routine programmatic or facility-related } \\
\text { sampling and analyzing efforts of operating } \\
\text { parameters. Some institutionally required chemical } \\
\text { analysis to protect ES\&H is performed by EPD and } \\
\text { the ES\&H Team. }\end{array}$ \\
\hline
\end{tabular}




\section{Conduct of Operations Applicability Matrix for Light Science \& Industry Facilities}

\begin{tabular}{|c|c|c|c|c|}
\hline $\begin{array}{l}\text { ES\&H MANUAL } \\
\text { DOCUMENT } 3.5 \\
\text { SECTION }\end{array}$ & $\begin{array}{l}\text { REQUISITES FOR SECTION } \\
\text { ELEMENTS }\end{array}$ & $\begin{array}{l}\text { APPLICABLE } \\
\text { YES/NO }\end{array}$ & $\begin{array}{l}\text { RESPONSIBILITY } \\
\text { FOR } \\
\text { COMPLIANCE } \\
\text { FMC/PMC }^{1}\end{array}$ & $\begin{array}{l}\text { COMMENTS AND/OR REFERENCE FOR } \\
\text { VERIFICATION OF COMPLIANCE }\end{array}$ \\
\hline \multicolumn{5}{|l|}{$\begin{array}{l}\text { REQUIRED } \\
\text { READING } \\
\text { SECTION } 14.0 \\
\end{array}$} \\
\hline 14.2.1. File Index & $\begin{array}{l}\text { Identify documents to be included in } \\
\text { each facility's required reading } \\
\text { program. }\end{array}$ & Yes & FMC/PMC & $\begin{array}{l}\text { FSPs are the only facility-level document identified } \\
\text { as required reading; all residents must read the } \\
\text { sections applicable to their work. Workers are } \\
\text { required to read the IWSs for their work. Each IWS } \\
\text { identifies any supplemental required reading for } \\
\text { each activity (e.g., SP, Hazard Assessment and } \\
\text { Control, Engineering Safety Note, etc.). }\end{array}$ \\
\hline \multirow[t]{2}{*}{$\begin{array}{l}\text { 14.2.2. Reading } \\
\text { Assignments }\end{array}$} & $\begin{array}{l}\text { Identify which documents must be } \\
\text { read by individuals (by position). }\end{array}$ & Yes & FMC/PMC & $\begin{array}{l}\text { FSPs are the only facility-level document identified } \\
\text { as required reading. Workers are required to read } \\
\text { the IWSs for their work. Each IWS identifies any } \\
\text { supplemental required reading for each activity } \\
\text { (e.g., SP, Hazard Assessment) }\end{array}$ \\
\hline & $\begin{array}{l}\text { Required reading documents should } \\
\text { be available in the facility or in the } \\
\text { program area. }\end{array}$ & Yes & FMC/PMC & $\begin{array}{l}\text { Documents identified in the IWSs are either } \\
\text { uploaded to the IWS or are maintained by the RI for } \\
\text { that activity. Facility specific documents are } \\
\text { maintained at: http://sodium.IInl.gov/cmels/ }\end{array}$ \\
\hline $\begin{array}{l}\text { 14.2.3. Required } \\
\text { Dates for Completion } \\
\text { of Reading }\end{array}$ & $\begin{array}{l}\text { Designate completion dates for } \\
\text { required reading. }\end{array}$ & Yes & FMC/PMC & $\begin{array}{l}\text { Formal FSP training is provided by CMELS, and } \\
\text { completion is documented in LTRAIN. } \\
\text { Each RI verifies that their employees complete the } \\
\text { required reading for their activity. Each employee } \\
\text { will electronically sign the IWSs for any IWS/SPs } \\
\text { under which they work. }\end{array}$ \\
\hline $\begin{array}{l}\text { 14.2.4. } \\
\text { Documentation }\end{array}$ & $\begin{array}{l}\text { Provide a system for documenting } \\
\text { that workers have completed the } \\
\text { required reading. }\end{array}$ & Yes & FMC/PMC & $\begin{array}{l}\text { Formal FSP training is provided by CMELS, and } \\
\text { completion is documented in LTRAIN. } \\
\text { Each RI verifies that their employees complete the } \\
\text { required reading for their activity. Each employee } \\
\text { will electronically sign the IWSs for any IWS/SPs } \\
\text { under which they work. }\end{array}$ \\
\hline
\end{tabular}




\section{Conduct of Operations Applicability Matrix for Light Science \& Industry Facilities}

\begin{tabular}{|c|c|c|c|c|}
\hline $\begin{array}{l}\text { ES\&H MANUAL } \\
\text { DOCUMENT } 3.5 \\
\text { SECTION }\end{array}$ & $\begin{array}{l}\text { REQUISITES FOR SECTION } \\
\text { ELEMENTS }\end{array}$ & $\begin{array}{l}\text { APPLICABLE } \\
\text { YES/NO }\end{array}$ & $\begin{array}{c}\text { RESPONSIBILITY } \\
\text { FOR } \\
\text { COMPLIANCE } \\
\text { FMC/PMC }^{1} \\
\end{array}$ & $\begin{array}{l}\text { COMMENTS AND/OR REFERENCE FOR } \\
\text { VERIFICATION OF COMPLIANCE }\end{array}$ \\
\hline 14.2.5. Review & $\begin{array}{l}\text { Regularly review and update the } \\
\text { required reading list. }\end{array}$ & Yes & FMC/PMC & $\begin{array}{l}\text { FSPs are reviewed and re-issued at least every } \\
\text { three years. }\end{array}$ \\
\hline \multicolumn{5}{|l|}{$\begin{array}{l}\text { TIMELY ORDERS } \\
\text { TO OPERATORS } \\
\text { SECTION } 15.0 \\
\end{array}$} \\
\hline \multirow[t]{2}{*}{$\begin{array}{l}\text { 15.2.1. Content and } \\
\text { Format }\end{array}$} & $\begin{array}{l}\text { Describe how special instructions } \\
\text { (short and long term) will be } \\
\text { developed for communication to } \\
\text { workers/operators. }\end{array}$ & Yes & FMC/PMC & $\begin{array}{l}\text { Instructions for work activities are identified through } \\
\text { the IWS for programmatic work activities. Facility } \\
\text { instructions (such as shut down of hoods or } \\
\text { retention tanks) are communicated by the Facility } \\
\text { Point of Contact to building residents through e-mail, } \\
\text { building announcements, paper postings, etc. } \\
\text { Special instructions to programmatic workers are } \\
\text { communicated directly by managers and } \\
\text { supervisors via e-mail, telephone, and/or personal } \\
\text { communication. }\end{array}$ \\
\hline & $\begin{array}{l}\text { Document how orders that are issued } \\
\text { to supplement operating procedures } \\
\text { will be incorporated. }\end{array}$ & Yes & FMC/PMC & $\begin{array}{l}\text { Instructions for work activities are identified through } \\
\text { the IWS for programmatic work activities. Facility } \\
\text { instructions (such as shut down of hoods or } \\
\text { retention tanks) are communicated by the Facility } \\
\text { Point of Contact to building residents through e-mail, } \\
\text { building announcements, paper postings, etc. } \\
\text { Special instructions to programmatic workers are } \\
\text { communicated directly by managers and } \\
\text { supervisors via e-mail, telephone, and/or personal } \\
\text { communication. }\end{array}$ \\
\hline \multirow[t]{2}{*}{$\begin{array}{l}\text { 15.2.2. Issuing, } \\
\text { Segregating, and } \\
\text { Reviewing Orders }\end{array}$} & $\begin{array}{l}\text { Describe process for issuing Shift } \\
\text { Orders/Instructions to } \\
\text { workers/operators. }\end{array}$ & Yes & FMC/PMC & $\begin{array}{l}\text { Instructions are issued through e-mail, building } \\
\text { announcements, phone calls, alpha-numeric pagers, } \\
\text { paper postings, in-person verbally, etc. }\end{array}$ \\
\hline & $\begin{array}{l}\text { Describe process for issuing Standing } \\
\text { Orders/Instructions to } \\
\text { workers/operators. }\end{array}$ & Yes & FMC/PMC & $\begin{array}{l}\text { Standing orders are documented and issued in the } \\
\text { work authorization documents (IWS's, PWS's, } \\
\text { Service Work Authorization docs, etc.). }\end{array}$ \\
\hline
\end{tabular}




\section{Conduct of Operations Applicability Matrix for Light Science \& Industry Facilities}

\begin{tabular}{|c|c|c|c|c|}
\hline $\begin{array}{l}\text { ES\&H MANUAL } \\
\text { DOCUMENT } 3.5 \\
\text { SECTION }\end{array}$ & $\begin{array}{c}\text { REQUISITES FOR SECTION } \\
\text { ELEMENTS }\end{array}$ & $\begin{array}{l}\text { APPLICABLE } \\
\text { YES/NO }\end{array}$ & $\begin{array}{l}\text { RESPONSIBILITY } \\
\text { FOR } \\
\text { COMPLIANCE } \\
\text { FMC/PMC }^{1} \\
\end{array}$ & $\begin{array}{l}\text { COMMENTS AND/OR REFERENCE FOR } \\
\text { VERIFICATION OF COMPLIANCE }\end{array}$ \\
\hline $\begin{array}{l}\text { 15.2.3. Removal of } \\
\text { Orders }\end{array}$ & $\begin{array}{l}\text { Remove/cancel expired or outdated } \\
\text { orders. }\end{array}$ & Yes & FMC/PMC & $\begin{array}{l}\text { Cancellation of standing orders are documented and } \\
\text { issued in the work authorization documents (IWS's, } \\
\text { PWS's, Service Work Authorization docs, etc). } \\
\text { Cancellation of shift orders is made through e-mail, } \\
\text { building announcements, phone calls, alpha- } \\
\text { numeric pagers, paper postings, in-person verbally, } \\
\text { etc. }\end{array}$ \\
\hline \multicolumn{5}{|l|}{$\begin{array}{l}\text { OPERATIONS } \\
\text { PROCEDURES } \\
\text { SECTION } 16.0\end{array}$} \\
\hline $\begin{array}{l}\text { 16.2.1. Procedure } \\
\text { Development }\end{array}$ & $\begin{array}{l}\text { Identify equipment/operations that } \\
\text { require operating procedures. }\end{array}$ & Yes & FMC/PMC & $\begin{array}{l}\text { The need for operating procedures in accordance } \\
\text { with Document } 3.4 \text { of the ES\&H Manual is } \\
\text { determined through the IWS process. } \\
\text { Equipment/systems that need operating procedures } \\
\text { from a programmatic impact standpoint are } \\
\text { managed in accordance with CMLS- } 901 \text {. } \\
\text { Instructions for equipment operation can also be } \\
\text { identified through the IWS for programmatic and } \\
\text { facility equipment. }\end{array}$ \\
\hline $\begin{array}{l}\text { 16.2.2. Procedure } \\
\text { Content }\end{array}$ & $\begin{array}{l}\text { Ensure that the content of operating } \\
\text { procedures conforms to prescribed } \\
\text { guidelines }\end{array}$ & Yes & FMC/PMC & $\begin{array}{l}\text { Document } 3.4 \text { of the ES\&H Manual defines } \\
\text { requirements for operating procedures. CMELS- } 904 \\
\text { (Control of Unclassified Management Documents) } \\
\text { defines CMELS requirements for work procedures. }\end{array}$ \\
\hline $\begin{array}{l}\text { 16.2.3. Procedure } \\
\text { Changes and } \\
\text { Revisions }\end{array}$ & $\begin{array}{l}\text { Specify a method for initiating } \\
\text { temporary and permanent changes to } \\
\text { operating procedures }\end{array}$ & Yes & FMC/PMC & $\begin{array}{l}\text { Document } 3.4 \text { of the ES\&H Manual defines } \\
\text { requirements for operating procedures. CMELS-904 } \\
\text { defines CMELS requirements for work procedures. }\end{array}$ \\
\hline $\begin{array}{l}\text { 16.2.4. Procedure } \\
\text { Approval }\end{array}$ & Identify procedure approval protocol. & Yes & FMC/PMC & $\begin{array}{l}\text { Document } 3.4 \text { of the ES\&H Manual defines } \\
\text { requirements for operating procedures. CMELS-904 } \\
\text { defines CMELS requirements for work procedures. }\end{array}$ \\
\hline $\begin{array}{l}\text { 16.2.5. Procedure } \\
\text { Review }\end{array}$ & Identify procedure review protocol. & Yes & FMC/PMC & $\begin{array}{l}\text { Document } 3.4 \text { of the ES\&H Manual defines } \\
\text { requirements for operating procedures. CMELS- } 904 \\
\text { defines CMELS requirements for work procedures. }\end{array}$ \\
\hline
\end{tabular}




\section{Conduct of Operations Applicability Matrix for Light Science \& Industry Facilities}

\begin{tabular}{|c|c|c|c|c|}
\hline $\begin{array}{l}\text { ES\&H MANUAL } \\
\text { DOCUMENT } 3.5 \\
\text { SECTION }\end{array}$ & $\begin{array}{c}\text { REQUISITES FOR SECTION } \\
\text { ELEMENTS }\end{array}$ & $\begin{array}{l}\text { APPLICABLE } \\
\text { YES/NO }\end{array}$ & $\begin{array}{l}\text { RESPONSIBILITY } \\
\text { FOR } \\
\text { COMPLIANCE } \\
\text { FMC/PMC }^{1} \\
\end{array}$ & $\begin{array}{l}\text { COMMENTS AND/OR REFERENCE FOR } \\
\text { VERIFICATION OF COMPLIANCE }\end{array}$ \\
\hline & $\begin{array}{l}\text { Ensure that new operating procedures } \\
\text { and those undergoing major revision } \\
\text { are verified for correctness and } \\
\text { operationally tested prior to final } \\
\text { approval and use. }\end{array}$ & Yes & FMC/PMC & $\begin{array}{l}\text { Document } 3.4 \text { of the ES\&H Manual defines } \\
\text { requirements for operating procedures. CMELS- } 904 \\
\text { defines CMELS requirements for work procedures. }\end{array}$ \\
\hline & $\begin{array}{l}\text { Review operating procedures to } \\
\text { ensure they are kept current. }\end{array}$ & Yes & $\mathrm{FMC} / \mathrm{PMC}$ & $\begin{array}{l}\text { Document } 3.4 \text { of the ES\&H Manual defines } \\
\text { requirements for operating procedures. In } \\
\text { accordance with the ES\&H Manual, FSPs are } \\
\text { updated at least every three years and IWS/SPs are } \\
\text { reviewed at least annually. CMELS-904 defines } \\
\text { CMELS requirements for work procedures. }\end{array}$ \\
\hline $\begin{array}{l}\text { 16.2.6. Procedure } \\
\text { Availability }\end{array}$ & $\begin{array}{l}\text { Copies of applicable operating } \\
\text { procedures are available and } \\
\text { controlled. }\end{array}$ & Yes & FMC/PMC & $\begin{array}{l}\text { Document } 3.4 \text { of the ES\&H Manual defines } \\
\text { requirements for operating procedures. CMELS-904 } \\
\text { defines CMELS requirements for work procedures. } \\
\text { Rls routinely upload current copies of relevant } \\
\text { procedures and safety plans to their IWSs. Facility- } \\
\text { specific documents are maintained at: } \\
\text { http://sodium.IInl.gov/cmels/ }\end{array}$ \\
\hline $\begin{array}{l}\text { 16.2.7. Procedure } \\
\text { Use }\end{array}$ & $\begin{array}{l}\text { Operators/Workers should be } \\
\text { instructed in the use of procedures. }\end{array}$ & Yes & $\mathrm{FMC} / \mathrm{PMC}$ & $\begin{array}{l}\text { Document } 3.4 \text { of the ES\&H Manual defines } \\
\text { requirements for operating procedures. CMELS-904 } \\
\text { defines CMELS requirements for work procedures. } \\
\text { Rls routinely upload current copies of relevant } \\
\text { procedures and safety plans to their IWSs. Facility- } \\
\text { specific documents are maintained at: } \\
\text { http://sodium.IInl.gov/cmels/ } \\
\text { Activity Responsible Individuals are responsible to } \\
\text { ensuring that workers are trained in the proper use } \\
\text { of applicable procedures. }\end{array}$ \\
\hline
\end{tabular}




\section{Conduct of Operations Applicability Matrix for Light Science \& Industry Facilities}

\begin{tabular}{|c|c|c|c|c|}
\hline $\begin{array}{l}\text { ES\&H MANUAL } \\
\text { DOCUMENT } 3.5 \\
\text { SECTION }\end{array}$ & $\begin{array}{l}\text { REQUISITES FOR SECTION } \\
\text { ELEMENTS }\end{array}$ & $\begin{array}{l}\text { APPLICABLE } \\
\text { YES/NO }\end{array}$ & $\begin{array}{l}\text { RESPONSIBILITY } \\
\text { FOR } \\
\text { COMPLIANCE } \\
\text { FMC/PMC }{ }^{1}\end{array}$ & $\begin{array}{l}\text { COMMENTS AND/OR REFERENCE FOR } \\
\text { VERIFICATION OF COMPLIANCE }\end{array}$ \\
\hline \multicolumn{5}{|l|}{$\begin{array}{l}\text { OPERATOR AID } \\
\text { POSTINGS } \\
\text { SECTION } 17.0\end{array}$} \\
\hline $\begin{array}{l}\text { 17.2.1. Operator Aid } \\
\text { Development }\end{array}$ & $\begin{array}{l}\text { Identify and maintain operator aids } \\
\text { that must be controlled. }\end{array}$ & No & NA & $\begin{array}{l}\text { Operator aids whose accuracy is critical to operating } \\
\text { a system or piece of equipment so that it does not } \\
\text { produce a significant impact to health, safety, the } \\
\text { environment, or programs are not used in these } \\
\text { facilities. }\end{array}$ \\
\hline 17.2.2. Approval & $\begin{array}{l}\text { Identify the individual responsible for } \\
\text { approving operator aids. }\end{array}$ & No & NA & $\begin{array}{l}\text { Operator aids whose accuracy is critical to operating } \\
\text { a system or piece of equipment so that it does not } \\
\text { produce a significant impact to health, safety, the } \\
\text { environment, or programs are not used in these } \\
\text { facilities. }\end{array}$ \\
\hline \multirow[t]{2}{*}{ 17.2.3. Posting } & $\begin{array}{l}\text { Ensure that operator aids are posted } \\
\text { so that they do not obscure or } \\
\text { interfere with instruments or controls. }\end{array}$ & No & NA & $\begin{array}{l}\text { Operator aids whose accuracy is critical to operating } \\
\text { a system or piece of equipment so that it does not } \\
\text { produce a significant impact to health, safety, the } \\
\text { environment, or programs are not used in these } \\
\text { facilities. }\end{array}$ \\
\hline & $\begin{array}{l}\text { Ensure that operator aids are legible } \\
\text { and posted as close as practical to } \\
\text { the system or equipment with which } \\
\text { they are associated. }\end{array}$ & No & NA & $\begin{array}{l}\text { Operator aids whose accuracy is critical to operating } \\
\text { a system or piece of equipment so that it does not } \\
\text { produce a significant impact to health, safety, the } \\
\text { environment, or programs are not used in these } \\
\text { facilities. }\end{array}$ \\
\hline $\begin{array}{l}\text { 17.2.4. Use of } \\
\text { Operator Aids }\end{array}$ & $\begin{array}{l}\text { Operator aid developers and users } \\
\text { should understand their purpose (e.g. } \\
\text { convenience, not requirement, } \\
\text { supplement to approved procedures) } \\
\text { and limitation (not used in lieu of } \\
\text { approved procedure) }\end{array}$ & No & NA & $\begin{array}{l}\text { Operator aids whose accuracy is critical to operating } \\
\text { a system or piece of equipment so that it does not } \\
\text { produce a significant impact to health, safety, the } \\
\text { environment, or programs are not used in these } \\
\text { facilities. }\end{array}$ \\
\hline
\end{tabular}




\section{Conduct of Operations Applicability Matrix for Light Science \& Industry Facilities}

\begin{tabular}{|c|c|c|c|c|}
\hline $\begin{array}{l}\text { ES\&H MANUAL } \\
\text { DOCUMENT } 3.5 \\
\text { SECTION }\end{array}$ & $\begin{array}{l}\text { REQUISITES FOR SECTION } \\
\text { ELEMENTS }\end{array}$ & $\begin{array}{l}\text { APPLICABLE } \\
\text { YES/NO }\end{array}$ & $\begin{array}{l}\text { RESPONSIBILITY } \\
\text { FOR } \\
\text { COMPLIANCE } \\
\text { FMC/PMC }^{1} \\
\end{array}$ & $\begin{array}{l}\text { COMMENTS AND/OR REFERENCE FOR } \\
\text { VERIFICATION OF COMPLIANCE }\end{array}$ \\
\hline $\begin{array}{l}\text { 17.2.5. } \\
\text { Documentation }\end{array}$ & $\begin{array}{l}\text { Maintain a listing of all approved } \\
\text { operator aids. }\end{array}$ & No & NA & $\begin{array}{l}\text { Operator aids whose accuracy is critical to operating } \\
\text { a system or piece of equipment so that it does not } \\
\text { produce a significant impact to health, safety, the } \\
\text { environment, or programs are not used in these } \\
\text { facilities. }\end{array}$ \\
\hline 17.2.6. Review & $\begin{array}{l}\text { Ensure that operator aids are } \\
\text { regularly reviewed to verify they are } \\
\text { current and appropriate. }\end{array}$ & No & NA & $\begin{array}{l}\text { Operator aids whose accuracy is critical to operating } \\
\text { a system or piece of equipment so that it does not } \\
\text { produce a significant impact to health, safety, the } \\
\text { environment, or programs are not used in these } \\
\text { facilities. }\end{array}$ \\
\hline \multicolumn{5}{|l|}{$\begin{array}{l}\text { EQUIPMENT AND } \\
\text { PIPING LABELING } \\
\text { SECTION } 18.0 \\
\end{array}$} \\
\hline $\begin{array}{l}\text { 18.2.1. Components } \\
\text { Requiring Labeling }\end{array}$ & $\begin{array}{l}\text { Identify and maintain a listing of } \\
\text { equipment and piping that should be } \\
\text { labeled in accordance with section } \\
\text { 18.2.1. }\end{array}$ & Yes & FMC/PMC & $\begin{array}{l}\text { Plant Engineering Standards PEL-M-11009, (Rev. G } \\
\text { or latest revision) for equipment, and PEL-M-02650, } \\
\text { (Rev. A or latest revision) for piping and valve } \\
\text { identification. }\end{array}$ \\
\hline \multirow[t]{2}{*}{$\begin{array}{l}\text { 18.2.2. Label } \\
\text { Information }\end{array}$} & $\begin{array}{l}\text { Use the Plant Engineering } \\
\text { Department standards for label } \\
\text { requirements and abbreviations. }\end{array}$ & Yes & FMC/PMC & $\begin{array}{l}\text { Plant Engineering Standards PEL-M-11009, (Rev. G } \\
\text { or latest revision) for equipment, and PEL-M-02650, } \\
\text { (Rev. A or latest revision) for piping and valve } \\
\text { identification. }\end{array}$ \\
\hline & $\begin{array}{l}\text { Ensure workers are trained or } \\
\text { instructed before performing } \\
\text { maintenance on labeled equipment. }\end{array}$ & Yes & FMC/PMC & $\begin{array}{l}\text { Plant Engineering Standards PEL-M-11009, (Rev. G } \\
\text { or latest revision) for equipment, and PEL-M-02650, } \\
\text { (Rev. A or latest revision) for piping and valve } \\
\text { identification. }\end{array}$ \\
\hline $\begin{array}{l}\text { 18.2.3. Label } \\
\text { Placement }\end{array}$ & $\begin{array}{l}\text { Use Plant Engineering Standards } \\
\text { PEL-M-11009, (Rev. G or latest } \\
\text { revision) (for equipment) and PEL-M- } \\
\text { 02650, (Rev. A or latest revision) (for } \\
\text { piping and valve identification) for } \\
\text { label placement. }\end{array}$ & Yes & FMC/PMC & $\begin{array}{l}\text { Plant Engineering Standards PEL-M-11009, (Rev. G } \\
\text { or latest revision) for equipment, and PEL-M- } 02650 \text {, } \\
\text { (Rev. A or latest revision) for piping and valve } \\
\text { identification. }\end{array}$ \\
\hline
\end{tabular}




\section{Conduct of Operations Applicability Matrix for Light Science \& Industry Facilities}

\begin{tabular}{|l|l|l|c|l|}
\hline $\begin{array}{c}\text { ES\&H MANUAL } \\
\text { DOCUMENT 3.5 } \\
\text { SECTION }\end{array}$ & \multicolumn{1}{|c|}{$\begin{array}{c}\text { REQUISITES FOR SECTION } \\
\text { ELEMENTS }\end{array}$} & $\begin{array}{c}\text { RESPONSIBILITY } \\
\text { FPPLICABLE } \\
\text { YES/NO }\end{array}$ & $\begin{array}{c}\text { FOR } \\
\text { COMPLIANCE } \\
\text { FMC/PMC }\end{array}$ & $\begin{array}{c}\text { COMMENTS AND/OR REFERENCE FOR } \\
\text { VERIFICATION OF COMPLIANCE }\end{array}$ \\
\hline $\begin{array}{l}\text { 18.2.4. Replacing } \\
\text { Labels }\end{array}$ & $\begin{array}{l}\text { Ensure processes (e.g. post- } \\
\text { maintenance tests, lineup sheets, } \\
\text { etc.) include provisions to check for } \\
\text { labels that are missing, damaged or } \\
\text { have incorrect information and new } \\
\text { labels are promptly provided. }\end{array}$ & Yes & FMC/PMC & $\begin{array}{l}\text { Plant Engineering Standards PEL-M-11009, (Rev. G } \\
\text { or latest revision) for equipment, and PEL-M-02650, } \\
\text { (Rev. A or latest revision) for piping and valve } \\
\text { identification. }\end{array}$ \\
\hline
\end{tabular}

